\title{
The Opportunities and Challenges of Peroxisome Proliferator-Activated Receptors Ligands in Clinical Drug Discovery and Development
}

\author{
Fan Hong ${ }^{1,2}$, Pengfei $\mathrm{Xu}^{1, *, \dagger}$ and Yonggong Zhai ${ }^{1,2, *}$ \\ 1 Beijing Key Laboratory of Gene Resource and Molecular Development, College of Life Sciences, \\ Beijing Normal University, Beijing 100875, China; hongfanky@126.com \\ 2 Key Laboratory for Cell Proliferation and Regulation Biology of State Education Ministry, \\ College of Life Sciences, Beijing Normal University, Beijing 100875, China \\ * $\quad$ Correspondence: pex9@pitt.edu (P.X.); ygzhai@bnu.edu.cn (Y.Z.); Tel.: +86-156-005-60991 (P.X.); \\ +86-10-5880-6656 (Y.Z.) \\ + Current address: Center for Pharmacogenetics and Department of Pharmaceutical Sciences, \\ University of Pittsburgh, Pittsburgh, PA 15213, USA.
}

Received: 22 June 2018; Accepted: 24 July 2018; Published: 27 July 2018

\begin{abstract}
Peroxisome proliferator-activated receptors (PPARs) are a well-known pharmacological target for the treatment of multiple diseases, including diabetes mellitus, dyslipidemia, cardiovascular diseases and even primary biliary cholangitis, gout, cancer, Alzheimer's disease and ulcerative colitis. The three PPAR isoforms $(\alpha, \beta / \delta$ and $\gamma)$ have emerged as integrators of glucose and lipid metabolic signaling networks. Typically, PPAR $\alpha$ is activated by fibrates, which are commonly used therapeutic agents in the treatment of dyslipidemia. The pharmacological activators of PPAR $\gamma$ include thiazolidinediones (TZDs), which are insulin sensitizers used in the treatment of type 2 diabetes mellitus (T2DM), despite some drawbacks. In this review, we summarize 84 types of PPAR synthetic ligands introduced to date for the treatment of metabolic and other diseases and provide a comprehensive analysis of the current applications and problems of these ligands in clinical drug discovery and development.
\end{abstract}

Keywords: PPAR; ligand; T2DM; dyslipidemia; TZDs

\section{Introduction}

Peroxisome proliferator-activated receptors (PPARs) are a group of nuclear receptors (NRs) that play essential roles in the regulation of several physiological processes, including cellular differentiation and development, whole-body energy homeostasis (carbohydrate, lipid, protein) and tumorigenesis [1]. PPARs are ligand-activated transcription factors and consist of a DNA binding domain in the $\mathrm{N}$-terminus and a ligand binding domain (LBD) in the C-terminus [2,3]. The family of PPARs comprises three isoforms: PPAR $\alpha$ (NR1C1), PPAR $\beta / \delta$ (NR1C2) and PPAR $\gamma$ (NR1C3) [2] and their 3D structures are shown in Figure 1. PPAR $\alpha$ is highly expressed in metabolically active tissues and PPAR $\gamma$ which has three forms: PPAR $\gamma 1, \operatorname{PPAR} \gamma 2$ and PPAR $\gamma 3$ is mainly expressed in white and brown adipose tissue [4]. The least known isoform is PPAR $\beta / \delta$, which is expressed ubiquitously in virtually all tissues. After interaction with agonists, PPARs are translocated to the nucleus, where they heterodimerize with the retinoid X receptor (RXR) [5]. Then, PPAR-PXR binds to peroxisome proliferator hormone response elements (PPREs) [2] and regulates target genes. All three PPARs have natural agonists, namely, a variety of polyunsaturated long-chain fatty acids and arachidonic acid derivatives.

PPARs regulate genes that are important in cell differentiation and various metabolic processes, especially lipid and glucose metabolism. In both rodents and humans, PPARs are genetic sensors 
for lipids and modulate genes through the promotion of reverse cholesterol transport, reduction of total triglycerides (TGs) and regulation of apolipoproteins, thermogenesis and glucose metabolism. PPAR $\alpha$ regulates the catabolism of fatty acids in the liver by inducing the expression of fatty acid transport protein (FATP) [6], FAT [7], long-chain fatty acid acetyl-CoA synthase (ACS) [8], enoyl-CoA hydratase/dehydrogenase multifunctional enzyme [9] and keto-acyl-CoA thiolase [10] enzymes. PPAR $\gamma$ influences the storage of fatty acids in adipose tissue by regulating the expression of numerous genes, including AP2 [11], PEPCK [12], acyl-CoA synthase [13] and LPL [14]. Furthermore, PPAR $\beta / \delta$ activation also improves lipid homeostasis, prevents weight gain and increases insulin sensitivity [15]. Accordingly, PPARs are considered important targets for the treatment of metabolic syndrome and choreographers of metabolic gene transcription.

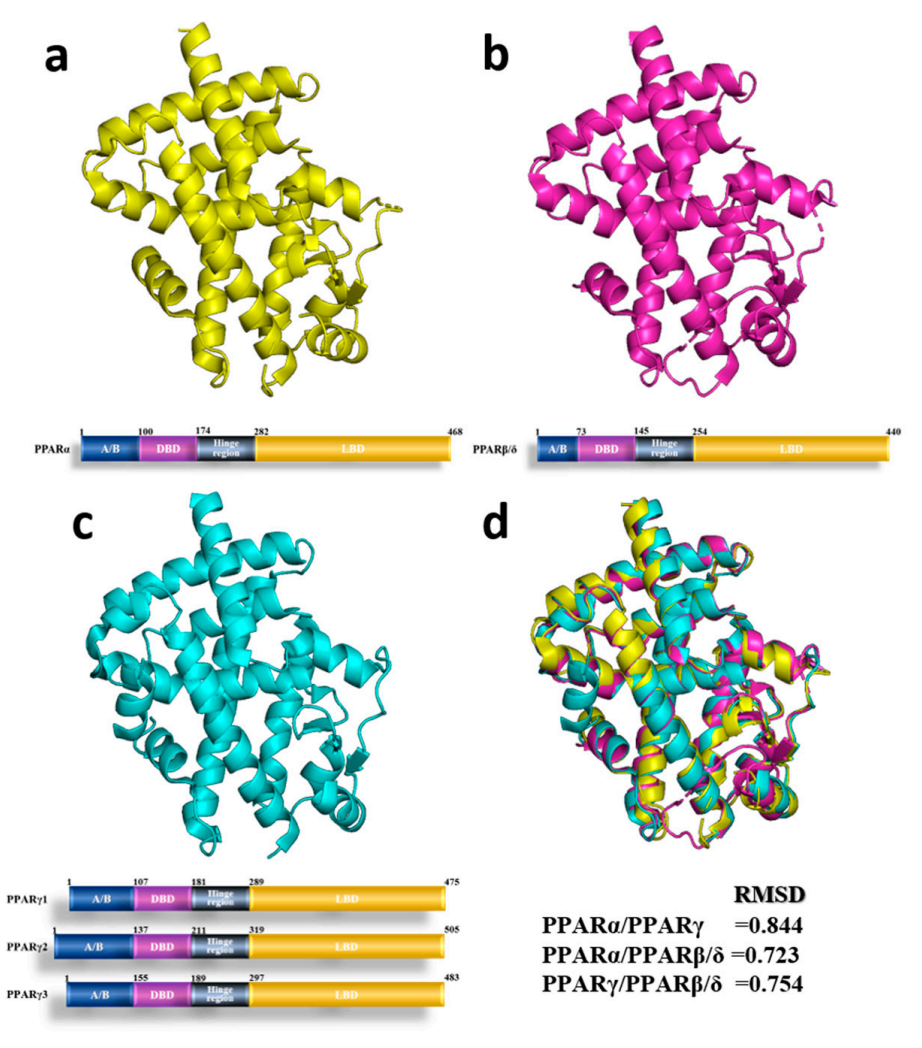

Figure 1. 3D structure and schematic structure of human Peroxisome proliferator-activated receptors (PPARs). 3D structure and schematic structure of PPAR $\alpha$ (1I7G [16]) (a) PPAR $\beta / \delta$ (1GWX [17]) (b) and PPAR $\gamma$ (1FM6 [18]) (c,d) 3D structure superposition of PPAR $\alpha$ (yellow), PPAR $\beta / \delta$ (magenta) and $\operatorname{PPAR} \gamma$ (cyan) and RMSD value of three PPARs within pairwise comparison.

PPARs are also called lipid and insulin sensors [2]. Hence, many synthetic agonists of PPARs have different properties and specificities, having been developed for the treatment of different clinical outcomes over the past several decades [19-21]. For example, PPAR $\alpha$ activators such as fibrates (fenofibrate, clofibrate) are useful drugs for the treatment of dyslipidemia. They increase HDL, decrease TG and have no effects on low-density lipoprotein (LDL). PPAR $\gamma$ is a target of synthetic insulin sensitizers thiazolidinediones (TZDs), including pioglitazone and rosiglitazone, which were used in the treatment of type 2 diabetes mellitus (T2DM). Dual agonists of PPAR $\alpha / \gamma$, such as glitazar, have been developed and have recently become available for the combined treatment of T2DM and dyslipidemia. Of course, there are many drugs targeting PPARs for the clinical treatment of various diseases. However, many drugs have been limited or terminated in the clinical stage by their side effect profiles. TZDs are well known to have prompted an alert by the US Food and Drug Administration (FDA) due to adverse effects, such as fluid retention, congestive heart failure (CHF) and adipogenic 
weight gain [22]. In this review, we summarize the use of some PPAR agonists in therapeutic treatment, with a focus on both the pros and the cons of PPARs as key regulators of glucose and lipid metabolism. Thus far, current clinical data exists for the use of 84 PPAR ligands for the treatment of diabetes mellitus, lipid metabolism disorder and other diseases (Table 1).

Table 1. Medications of PPAR synthetic ligands in currently clinical applications or studies.

\begin{tabular}{cccccc}
\hline \multirow{2}{*}{ Indication } & \multicolumn{5}{c}{ Development Status } \\
\cline { 2 - 6 } & In Market & Withdrawn & Clinical Research & Discontinued in Clinical Research & \\
\hline Type 2 diabetes & 3 & 1 & 5 & 23 & 32 \\
\hline Diabetic diseases & 1 & 0 & 5 & 10 & 16 \\
\hline Dyslipidemia & 7 & 0 & 6 & 8 & 21 \\
\hline CVDs & 0 & 0 & 1 & 1 & 2 \\
\hline Other diseases & 0 & 0 & 12 & 1 & 13 \\
\hline
\end{tabular}

\section{PPAR Ligand Therapeutics in Diabetes Mellitus}

Diabetes mellitus is a chronic, "whole-life" condition that increases the body's blood glucose levels. There are three main types of diabetes: type 1 diabetes (insulin dependent), T2DM (insulin resistance or insulin insensitivity) and gestational diabetes [23]. Diabetes mellitus and diabetic complications constitute the most important economic cost of the disease and represent a significant economic burden for the healthcare systems of developed countries [24]. As important modulators of lipid and glucose metabolism, PPAR ligands were used to treat T2DM and diabetes-associated complications.

\subsection{Type 2 Diabetes}

The majority of patients with diabetes are diagnosed with T2DM, which affects at least 250 million people worldwide [25]. Insulin resistance is a major determinant of T2DM, which involves some defects of response to pancreatic insulin in muscle and liver cell [26]. The main treatment for diabetes mellitus is to lower the blood glucose levels to reach as close to normal as possible. Many pharmacological agents are utilized in patients with type 2 diabetes, such as TZDs, biguanide, GLP-1 agonists, DPP-4 inhibitors and SGLT2s. Here, we summarize the market value of the ligands of PPAR-treated type 2 diabetes (Table 2).

TZDs, as PPAR $\gamma$ agonists, are increasingly being used to counteract the effects of diabetes by regulating the transcription of insulin-responsive genes, thereby enhancing insulin sensitivity in adipose tissue, skeletal muscle and liver to help reduce plasma glucose and insulin [26]. TZDs were developed in the late $1990 \mathrm{~s}$ and have been used to treat up to $26 \%$ of people with diabetes mellitus [27]. In the market, the main approved TZD drugs for the treatment of type 2 diabetes are rosiglitazone, pioglitazone, lobeglitazone sulfate and these drugs often used combination with metformin or other antidiabetic drugs. Rosiglitazone (Rosiglitazone Maleate) is a pure ligand of PPAR $\gamma$ without PPAR $\alpha$-binding action [28]. The pharmaceutical company GlaxoSmithKline (Brentford, UK) marketed it as Avandia ${ }^{\circledR}$, a standalone preparation and combined it with metformin as a compound (Avandamet). Another combination drug approved by the FDA is Avandaryl ${ }^{\circledR}$ (with glimepiride) [29]. Studies on animal models of insulin resistance and diabetes have shown that rosiglitazone prevents the onset of hyperglycemia, proteinuria and pancreatic islet cell degeneration [23]. In patients with T2DM, rosiglitazone reduces fasting plasma glucose (FPG), $\mathrm{HbA1c}$, insulin, C-peptide and postprandial serum glucose [30]. However, in rosiglitazone monotherapy, clinically significant side effects such as edema, anemia and weight gain are frequently reported with a conventional dosage of drug [31]. Moreover, patients with unstable heart failure (HF) and patients with a history of myocardial infarction (MI) should avoid the use of rosiglitazone due to the increased risk of cardiovascular disease (CVD) [32]. Pioglitazone hydrochloride is the hydrochloride salt of thiazolidinedione with antidiabetic properties and potential antineoplastic activity [33]. Pioglitazone monotherapy significantly improves $\mathrm{HbA1c}$ 
and FPG while producing beneficial effects on serum lipids in patients with type 2 diabetes with no evidence of drug-induced hepatotoxicity [34]. However, raising the dose and time of pioglitazone use increased the risk of bladder cancer and reached statistical significance after 24 months of exposure. Thus, the FDA issued an alert about a potential relation between the incidence of bladder cancer and the prescription of pioglitazone [35]. However, a recent meta-analysis based on 193,099 persons in the bladder cancer cohort conservatively suggested that pioglitazone use was not associated with a statistically significant increased risk of bladder cancer [36]. Given the many adverse effects of troglitazone, combination therapy can better treat type 2 diabetes. Alogliptin benzoate, a dipeptidyl peptidase-4 inhibitor, has a blood glucose-dependent insulinotropic effect via elevated concentrations of glucagon-like peptide-1 [37,38]. Pioglitazone/alogliptin combination therapy was effective and generally well tolerated in Japanese subjects with T2DM and is considered to be useful in clinical settings [39].

Table 2. Approved drugs of PPAR ligands for type 2 diabetes treatment.

\begin{tabular}{cccc}
\hline Generic Name & Type of PPAR Agonist & Molecular Weight & Company \\
\hline Rosiglitazone Maleate & PPAR $\gamma$ agonist & 473.5 & GlaxoSmithKline \\
\hline Pioglitazone Hydrochloride & PPAR $\gamma$ agonist & 392.898 & Takeda(Originator) Lilly \\
\hline Lobeglitazone Sulfate & Dual PPAR $\alpha / \gamma$ agonist & 578.61 & Chong Kun Dang \\
\hline
\end{tabular}

Lobeglitazone sulfate, a novel PPAR $\gamma$ agonist, was conceptually designed by modification of the rosiglitazone structure with a substituted pyrimidine [40]. Lobeglitazone has a $p$-methoxyphenoxy group at the 4-position of the pyrimidine moiety [41] and is structurally similar to two well-known TZD drugs, rosiglitazone and pioglitazone. These substituted pyrimidines were selected based on their empirical effects on triglyceride accumulation in adipocytes in vitro and their glucose-lowering and lipid-modulating activities in diabetic mice in vivo [42,43]. In contrast to other TZDs, lobeglitazone is mainly excreted in the feces, reducing the concerns about the risk of bladder cancer in the mice [44] and rats [45]. In the study of lobeglitazone in patients with T2DM, lobeglitazone showed a favorable balance of efficacy and safety during the extension study [46]. In pharmacokinetic studies in healthy adults, lobeglitazone was well tolerated and did not significantly affect the pharmacokinetics of metformin or vice versa [47]. In addition, the glucose-lowering effect of lobeglitazone is more promising in obese patients with inadequate glycemic control, long-term diabetes and severe insulin resistance.

The full activation of PPAR $\gamma$ is related to the phosphorylation of PPAR $\gamma$ Ser273, which results in a series of side effects [48]. Therefore, many new insulin sensitizers based on the pharmacology of the TZDs for clinical use have focused on the selective activation of PPARs in the clinical stage. Here, we summarize the PPAR ligands used to treat type 2 diabetes in the clinical stage (Table 3).

Table 3. Drugs of PPAR ligands for type 2 diabetes treatment in clinical stage.

\begin{tabular}{ccccc}
\hline Generic Name & Type of PPAR Agonist & Molecular Weight & Company & Development Status \\
\hline Chiglitazar & PPARs agonist & 594.61 & ChipScreen & Phase III active \\
\hline KDT-501 & PPAR $\alpha$ agonists & 404.588 & $\begin{array}{c}\text { KinDex } \\
\text { Pharmaceuticals }\end{array}$ & Phase II active \\
\hline Naveglitazar & PPAR modulator & 422.477 & $\begin{array}{c}\text { Lilly(Originator)Ligand } \\
\text { (Originator) }\end{array}$ & Phase II Pending \\
\hline AVE-0897 & Dual PPAR $\alpha / \gamma$ agonist & 469 & Genfit(Originator)Sanofi & Phase I active \\
\hline ZY-H2 & Dual PPAR $\alpha / \gamma$ agonist & unknown & Zydus cadila & Phase I Pending \\
\hline
\end{tabular}

Chiglitazar is a configuration-restricted non-TZD PPAR pan agonist with AC50 values of 1.2, 0.08 and $1.7 \mu \mathrm{M}$ in CV- 1 cells for PPAR $\alpha$, PPAR $\gamma$ and PPAR $\delta$, respectively and is currently in phase III clinical development in China [49]. In animal studies, chiglitazar demonstrated comparable 
antidiabetic effects to those of rosiglitazone but had fewer adverse effects involving body weight and fat pad weight increases in KKAy and $\mathrm{db} / \mathrm{db}$ diabetic mouse models. Clinical studies (phase IIa and $\mathrm{IIb}$ ) also show that the complete dose range of chiglitazar has a well-tolerated safety profile in patients with T2DM [49]. Its overall encouraging profile in terms of efficacy versus toxicity might be related to the balanced activity of chiglitazar towards different PPAR subtypes [49]. KDT-501 is a compound chemically derived from hops that has antidiabetic effects in rodents [50]. Multiplex analysis of gene expression revealed that KDT-501 enhanced the expression of PGC1 $\alpha$ and PPAR $\alpha$ but showed no evidence of activating PPAR $\gamma$ [51]. The oral administration of KDT-501 in DIO mouse and ZDF rat models of diabetes reduced plasma $\mathrm{HbA1c}$ and improved glucose metabolism. A recent study showed that KDT-501 treatment reduced plasma triglyceride levels in an open-label, phase II clinical trial including nine obese, insulin-resistant subjects [52]. Plasma total and high-molecular-weight (HMW) adiponectin were higher and plasma tumor necrosis factor alpha $(\mathrm{TNF} \alpha)$ also reduced after KDT-501 treatment [52].

Many other drugs are currently in clinical studies, including naveglitazar (phase II, Lilly (Indianapolis, IN, USA)), AVE-0897 (phase I, Genfit (Originator) Sanofi) and ZY-H2 (phase I, Zydus Cadila (Ahmedabad, Gujarat, India)).

Due to safety and tolerability issues such as weight gain, edema, CHF and bone fracture, many drugs have been terminated during the clinical research stage. For example, a class of pharmaceutical molecules exhibiting PPAR $\alpha / \gamma$ dual effects is known as the "glitazars," including aleglitazar, ragaglitazar, tesaglitazar, sipoglitazar, muraglitazar, cevoglitazar and naveglitazar [53]. They have been investigated for potential use in treating T2DM and dyslipidemia simultaneously. Here, we summarize the "glitazar" drugs for the treatment of T2DM that were terminated in the clinical research stage (Table 4).

Table 4. Dual PPAR $\alpha / \gamma$ agonist "glitazar" for type 2 diabetes treatment.

\begin{tabular}{ccccc}
\hline Generic Name & Type of PPAR Agonist & Molecular Weight & Company & Development Status \\
\hline Aleglitazar & Dual PPAR $\alpha / \gamma$ agonist & 437.51 & Roche & Phase III discontinued \\
\hline Ragaglitazar & Dual PPAR $\alpha / \gamma$ agonist & 419.477 & $\begin{array}{c}\text { Novo Nordisk } \\
\text { Pharmaceutical }\end{array}$ & Phase III discontinued \\
\hline Imiglitazar & Dual PPAR $\alpha / \gamma$ agonist & 470.525 & Takeda & Phase III discontinued \\
\hline Tesaglitazar & Dual PPAR $\alpha / \gamma$ agonist & 408.465 & AstraZeneca & Phase III discontinued \\
\hline Peliglitazar & Dual PPAR $\alpha / \gamma$ agonist & 530.577 & Bristol-Myers Squibb & Phase II discontinued \\
\hline Farglitazar & Dual PPAR $\alpha / \gamma$ agonist & 546.623 & GlaxoSmithKline & Phase II discontinued \\
\hline Sipoglitazar & $\begin{array}{c}\text { Dual PPAR } \alpha / \gamma \text { agonist; } \\
\text { Insulin } s e n s i t i z e r\end{array}$ & 463.552 & Takeda & Phase II discontinued \\
\hline Reglitazar & Dual PPAR $\alpha / \gamma$ agonist & 392.411 & $\begin{array}{c}\text { Japan } \\
\text { Tbacco(Originator) } \\
\text { Pfizer }\end{array}$ & Phase II discontinued \\
\hline Indeglitazar & Dual PPAR $\alpha / \gamma$ agonist & 389.422 & Pfizer & Phase II discontinued \\
\hline Muraglitazar & Dual PPAR $\alpha / \gamma$ agonist & 516.55 & Bristol-Myers Squibb & NDA Filing US \\
\hline
\end{tabular}

The dual PPAR $\alpha / \gamma$ agonist alegitazar exerts antihyperglycemic and lipid profile-modifying effects [54], leading to insulin-sensitizing and glucose-lowering activities and favorable effects on lipid profiles and biomarkers of cardiovascular risk [55]. However, the development of aleglitazar was halted because of a lack of cardiovascular efficacy and PPAR-related side effects in patients with T2DM post-acute coronary syndrome [56]. Ragaglitazar was mentioned as carcinogenic to the urinary bladder in Sprague-Dawley male rats exposed to $50 \mathrm{mg} / \mathrm{kg} /$ day (approximately 10 times the human exposure) in a 2-year carcinogenicity study [57]. Ragaglitazar was in phase III trials by Novo Nordisk (Copenhagen, Denmark) but was terminated in July 2002 because it caused urinary bladder tumors in mice [58]. Similarly, the development of tesaglitazar was discontinued because it severely increased 
serum creatinine in diabetic patients. Sipoglitazar, an azolealkanoic acid derivative, exhibits selective PPAR agonist activities towards PPARs. For example, sipoglitazar was used to treat patients with metabolic syndrome and T2DM through improving peripheral insulin sensitivity, lowering the lipid content of bodies and reducing body weight [59]. Sipoglitazar reached phase II clinical trials by Takeda for the treatment of diabetes; however, this research has been discontinued. The development of reglitazar, a PPAR $\gamma$ agonist that is structurally similar to TZDs and exhibits some degree of PPAR $\alpha$ activity, was discontinued due to its lower than expected efficacy after phase II clinical trials [60].

In brief, no "glitazar" drugs, which also include muraglitazar (NDA Filing US, Bristol-Myers Squibb (Ney York, NY, USA), imiglitazar (phase III, Takeda (Tokyo, Japan)), indeglitazar (phase II, Pfizer (Ney York, NY, USA)), farglitazar (phase II, GlaxoSmithKline) and peliglitazar (phase II, Bristol-Myers Squibb (Ney York, NY, USA)), has ever been approved for clinical use due primarily to the concern of cancer risk in animals, despite their promising effects on related metabolism.

In addition to "glitazar," other PPAR agonists for the treatment of T2DM have also halted development in the clinical research stage are lost development, as shown in Table 5.

Balaglitazone is a novel partial agonist of PPAR $\gamma$ that was developed by Dr. Reddy's laboratories in India. As a selective partial PPAR $\gamma$ agonist, balaglitazone presents a better safety profile than full agonists and cuts down $\mathrm{HbA1c}$ levels significantly. Balaglitazone provides robust glycemic control as an add-on to insulin therapy and a trend towards less severe side effects was observed in phase III trials [61]. However, the investment was halted in 2011. FK-614, a novel non-TZD PPAR $\gamma$ agonist, was as an antidiabetic agent and displays beneficial effect on improving insulin resistance [62]. FK-614 induces adipocyte differentiation by stimulating PPAR $\gamma$ in Zucker obese rats and altering WAT characteristics and improving systemic insulin sensitivity [63,64]. However, Astellas (Tokyo, Japan) (pharmaceutical company developing FK-614) has discontinued the development of FK-614 for the treatment of type 2 diabetes because its efficacy and safety parameters showed insufficient advantages over competitors [65]. Ciglitazone improves glycemic control by increasing insulin sensitivity [66]. Long-term use of ciglitazone treatment can significantly reduce blood glucose in diabetic $\mathrm{db} / \mathrm{db}$ mice, accompanied by recovery of glomerular immunopathology and renal tubular disorders [67]. Ciglitazone had been in phase II clinical trials by Takeda for the treatment of diabetes mellitus. However, this research has been discontinued [58]. In addition, many drugs are lost from development in the clinical stage, including rivoglitazone hydrochloride (phase III, Daiichi Sankyo (Tokyo, Japan)), ONO 5129 (phase II, Ono), EML-4156 (phase II, Merck Serono), netoglitazone; isoglitazone (phase II, Mitsubishi Tanabe Pharma (Originator) Perlegen Sciences), PN-2034 (phase II, Wellstat (Originator) Sanofi), Edaglitazone (phase II, Roche (Basel, Switzerland)), darglitazone sodium (phase I, Pfizer), AVE-5376 (phase I, Sanofi), DS-6930 (phase I, Daiichi Sankyo) and E-3030 (phase I, Eisai).

As mentioned above, in many clinical studies of TZDs targeting PPAR $\gamma$ have encountered problems with the adverse effects of TZDs and the use of these drugs has been limited, or they have been withdrawn from the markets in the United States, Europe and other countries [68]. However, the debate on the safety of TZDs continues and some scientists are also attempting to develop new classes of insulin sensitizers. Thus, there is still a need for novel TZDs. The selective modulation of PPAR $\gamma$ provides the opportunity to improve the safety profile while retaining the desirable therapeutic effects. 
Table 5. Drugs of PPAR ligands for treatment of type 2 diabetes discontinued in clinical stage.

\begin{tabular}{|c|c|c|c|c|}
\hline Generic Name & Type of PPAR Agonist & $\begin{array}{l}\text { Molecular } \\
\text { Weight }\end{array}$ & Company & $\begin{array}{c}\text { Development } \\
\text { Status }\end{array}$ \\
\hline Troglitazone & PPAR $\gamma$ agonists & 441.542 & $\begin{array}{c}\text { Daiichi Sankyo (Originator) } \\
\text { Pfizer }\end{array}$ & Withdrawn \\
\hline $\begin{array}{l}\text { Rivoglitazone } \\
\text { Hydrochloride }\end{array}$ & PPAR $\gamma$ agonists & 433.907 & $\begin{array}{c}\text { Daiichi Sankyo (Originator) } \\
\text { Santen }\end{array}$ & $\begin{array}{c}\text { Phase III } \\
\text { discontinued }\end{array}$ \\
\hline Balaglitazone & $\begin{array}{l}\text { Partial agonist of } \\
\text { PPAR } \gamma\end{array}$ & 395.433 & $\begin{array}{l}\text { Dr Reddy's Laboratories } \\
\text { (Originator) Rheoscience }\end{array}$ & $\begin{array}{c}\text { Phase II } \\
\text { discontinued }\end{array}$ \\
\hline FK-614 & $\begin{array}{l}\text { PPAR } \gamma \text { agonists; } \\
\text { Insulin sensitizer }\end{array}$ & 468.393 & $\begin{array}{l}\text { Astellas (Originator) } \\
\text { Aestus Therapeutics }\end{array}$ & $\begin{array}{c}\text { Phase II } \\
\text { discontinued }\end{array}$ \\
\hline Ciglitazone & PPAR agonists & 333.446 & Takeda & $\begin{array}{c}\text { Phase II } \\
\text { discontinued }\end{array}$ \\
\hline ONO 5129 & Dual PPAR $\alpha / \gamma$ agonist & unknown & Ono & $\begin{array}{c}\text { Phase II } \\
\text { discontinued }\end{array}$ \\
\hline EML-4156 & Dual PPAR $\alpha / \gamma$ agonist & 314.381 & Merck Serono & $\begin{array}{c}\text { Phase II } \\
\text { discontinued }\end{array}$ \\
\hline $\begin{array}{l}\text { Netoglitazone; } \\
\text { Isaglitazone }\end{array}$ & Dual PPAR $\alpha / \gamma$ agonist & 381.421 & $\begin{array}{l}\text { Mitsubishi Tanabe Pharma } \\
\text { (Originator) Perlegen Sciences }\end{array}$ & $\begin{array}{c}\text { Phase II } \\
\text { discontinued }\end{array}$ \\
\hline PN-2034 & $\operatorname{PPAR} \gamma$ agonist & unknown & Wellstat (Originator) Sanofi & $\begin{array}{c}\text { Phase II } \\
\text { discontinued }\end{array}$ \\
\hline Edaglitazone & PPAR $\gamma$ agonists & 464.554 & Roche & $\begin{array}{c}\text { Phase II } \\
\text { discontinued }\end{array}$ \\
\hline $\begin{array}{l}\text { Darglitazone } \\
\text { Sodium }\end{array}$ & Dual PPAR $\alpha / \gamma$ agonist & 442.465 & Pfizer & $\begin{array}{c}\text { Phase I } \\
\text { discontinued }\end{array}$ \\
\hline AVE-5376 & Dual PPAR $\alpha / \gamma$ agonist & unknown & Sanofi (Originator) & $\begin{array}{c}\text { Phase I } \\
\text { discontinued }\end{array}$ \\
\hline DS-6930 & PPAR $\gamma$ agonists & 136.129 & Daiichi Sankyo & $\begin{array}{c}\text { Phase I } \\
\text { discontinued }\end{array}$ \\
\hline E-3030 & Dual PPAR $\alpha / \gamma$ agonist & 481.93 & Eisai & $\begin{array}{c}\text { Phase I } \\
\text { discontinued }\end{array}$ \\
\hline
\end{tabular}

\subsection{Diabetes-Associated Complications}

Diabetes increases the risk of cardiovascular disease [25], retinopathy [69], renal failure [70] and peripheral vascular disease. Moreover, diabetes-associated complications and comorbidities also add to the lethality of T2DM [71]. Similarly, PPAR agonists have a good therapeutic effect on diabetes-associated complications, such as diabetic dyslipidemia, hypertension and Alzheimer's disease. Here, we summarize the PPAR ligands used to treat diabetes-associated, as shown in Table 6.

A very common metabolic abnormality associated with diabetes is dyslipidemia, which occurs in over $50 \%$ of T2DM patients and is often unresponsive to statin treatment [72,73]. Saroglitazar, a novel glitazar compound, is indicated mainly for T2DM patients for the treatment of diabetic dyslipidemia and hypertriglyceridemia not controlled by statin therapy [74]. Saroglitazar has shown dual PPAR $\alpha / \gamma$ agonism with a predominant PPAR $\alpha$ and moderate PPAR $\gamma$ activity has shown encouraging results at all stages of clinical trials. So far, Saroglitazar has been unrelated to any serious adverse events and it has not any adverse effects of weight gain and edema associated with TZDs [74]. Another drug used to improve dyslipidemia is HPP593, an effective selective PPAR $\delta$ agonist with no off-target activity. HPP593 exhibits an anti-diabetic effect in animal models of T2DM and also has demonstrated a reduction in LDL cholesterol and TGs and improved HDL cholesterol content. HPP593 is now in phase I clinical trials by High Point Pharmaceuticals (a subsidiary of vTv Therapeutics) for the 
treatment of diabetes and dyslipidemia [58]. K-111 is a new insulin-sensitizer with PPAR $\alpha$ activity but without PPAR $\gamma$ activity [75]. K-111 is structurally unrelated to thiazolidinediones; however, it has been shown to exert antihyperinsulinemic and lipid-lowering activity in rodents [75]. Furthermore, K-111 exhibits various pharmacological therapies for insulin sensitivity [76], dyslipidemia [77] and hypertension [78] in a nonhuman primate model. CLX-0921 is a weak activator of PPAR but retains effective glucose uptake activity in vitro and has equivalent glucose lowering activity in vivo to rosiglitazone. In addition, compared to rosiglitazone, CLX-0921 showed a 10-fold reduction in vitro adipogenic potential and increased glycogen synthesis, which is usually independent of rosiglitazone or pioglitazone [79]. In addition to treatment with diabetes, CLX-0921 has shown an inhibitory effect on lipopolysaccharides-induced TNF $\alpha$ production in human monocytes. Mechanistic studies showed that some of the effects of CLX-0921 are attributable to the inhibition of IKB phosphorylation and subsequent inhibition of NFKB activation, an effect not seen for other thiazolidinediones [80].

Table 6. Drugs of PPAR ligands for treatment of diabetic associated complications in market or clinical stage.

\begin{tabular}{cccccc}
\hline Generic Name & $\begin{array}{c}\text { Type of PPAR } \\
\text { Agonist }\end{array}$ & Indication & $\begin{array}{c}\text { Molecular } \\
\text { Weight }\end{array}$ & Company & $\begin{array}{c}\text { Development } \\
\text { Status }\end{array}$ \\
\hline Saroglitazar & $\begin{array}{c}\text { Dual PPAR } \alpha / \gamma \\
\text { agonist }\end{array}$ & Diabetic dyslipidemia & 439.57 & Zydus cadila & Approved \\
\hline AMG-131 & PPAR $\gamma$ agonist & $\begin{array}{c}\text { Type 2 diabetes; Multiple } \\
\text { sclerosis (MS) }\end{array}$ & 672.38 & $\begin{array}{c}\text { Amgen (Originator) } \\
\text { InteKrin Therapeutics }\end{array}$ & $\begin{array}{c}\text { Phase II } \\
\text { active }\end{array}$ \\
\hline K-111 & $\begin{array}{c}\text { PPAR } \alpha \\
\text { agonists }\end{array}$ & $\begin{array}{c}\text { Type 2 diabetes; } \\
\text { Hyperlipidemia }\end{array}$ & 379.75 & Roche & $\begin{array}{c}\text { Phase II } \\
\text { Pending }\end{array}$ \\
\hline CLX-0921 & PPAR $\gamma$ agonist & $\begin{array}{c}\text { Type 2 diabetes; } \\
\text { Rheumatoid arthritis (RA) }\end{array}$ & 519.568 & Theracos & $\begin{array}{c}\text { Phase II } \\
\text { Pending }\end{array}$ \\
\hline HPP 593 & PPAR & $\begin{array}{c}\text { Diabetes Dyslipidemia } \\
\text { unknown }\end{array}$ & vTv Therapeutics LLC & $\begin{array}{c}\text { Phase II } \\
\text { active }\end{array}$ \\
\hline SAR-351034 & PPAR agonists & $\begin{array}{c}\text { Type 2 diabetes; } \\
\text { Dyslipidemia }\end{array}$ & unknown & Sanofi & Phase I active \\
\hline
\end{tabular}

Among the patients with T2DM, approximately 10\% developed diabetic nephropathy (DN) [81]. DN remains the leading cause of end-stage renal disease (ESRD) in the United States [82]. In the process of diabetic glomerular damage, podocytopathy is extremely important [83]. PPAR $\gamma$ is located in all three types of glomerular cells with prominent expression in podocytes [84]. The endogenous lipid electrophile 10-nitrooctadec-9-enoic acid (nitro-oleic acid, NO2-OA) can target and activate PPAR $\gamma$. In animal models, NO2-OA has demonstrated benefits in a variety of metabolic and circulatory diseases, including hypertension [85] vascular neointimal proliferation [86], obesity with metabolic syndrome [87] and hyperglycemia in diabetes [88]. NO2-OA improved renal ischemia-reperfusion injury by inhibiting Bax translocation and activation and the subsequent mitochondria-dependent apoptotic cascade by regulating PPAR [89]. AMG-131, a novel, non-TZD, selective PPAR $\gamma$ modulator, is under development by InteKrin Therapeutics, Inc. for the treatment of T2DM and multiple sclerosis (MS). AMG-131 displays robust glucose-lowering activity in rodent models of diabetes while exhibiting a reduced side effect profile compared to marketed TZDs [90]. In phase I and II clinical trials, AMG-131 was well tolerated, without any serious adverse events or reports of fluid retention [91]. In addition, SAR-351034 is also a PPAR agonist intended for the treatment of diabetes and dyslipidemia.

Numerous dual PPAR agonists have been developed; however, because of collateral side effects, none of these agents apart from saroglitazar has been marketed. Here, we summarized the PPAR drugs for the treatment of diabetes-associated complications that were terminated in the clinical research stage (Table 7). 
Table 7. Drugs of PPAR ligands for treatment of diabetic associated complications terminated in clinical stage.

\begin{tabular}{|c|c|c|c|c|c|}
\hline Generic Name & $\begin{array}{c}\text { Type of PPAR } \\
\text { Agonist }\end{array}$ & Indication & $\begin{array}{l}\text { Molecular } \\
\text { Weight }\end{array}$ & Company & $\begin{array}{c}\text { Development } \\
\text { Status }\end{array}$ \\
\hline MK-0767 & $\begin{array}{c}\text { Dual PPAR } \alpha / \gamma \\
\text { agonist }\end{array}$ & $\begin{array}{l}\text { Type } 2 \text { diabetes; } \\
\text { Dyslipidemia }\end{array}$ & 422.36 & $\begin{array}{l}\text { Kyorin (Originator) } \\
\text { Merck Sharp \& Dohme }\end{array}$ & $\begin{array}{c}\text { Phase III } \\
\text { discontinued }\end{array}$ \\
\hline Cevoglitazar & $\begin{array}{l}\text { Dual } \operatorname{PPAR} \alpha / \gamma \\
\text { agonist }\end{array}$ & $\begin{array}{l}\text { Type } 2 \text { diabetes; } \\
\text { Lipodystrophy }\end{array}$ & 558.528 & Novartis & $\begin{array}{c}\text { Phase II } \\
\text { discontinued }\end{array}$ \\
\hline Sodelglitazar & $\begin{array}{l}\text { Pan-PPAR agonists; } \\
\text { Insulin sensitizer }\end{array}$ & $\begin{array}{l}\text { Type } 2 \text { diabetes; } \\
\text { Hyperlipidemia }\end{array}$ & 499.539 & GlaxoSmithKline & $\begin{array}{c}\text { Phase II } \\
\text { discontinued }\end{array}$ \\
\hline AVE-0847 & $\begin{array}{c}\text { Dual } \operatorname{PPAR} \alpha / \gamma \\
\text { agonist }\end{array}$ & $\begin{array}{l}\text { Type } 2 \text { diabetes; } \\
\text { Lipodystrophy }\end{array}$ & unknown & Sanofi & $\begin{array}{c}\text { Phase II } \\
\text { discontinued }\end{array}$ \\
\hline KRP-101 & PPAR $\alpha$ agonists & $\begin{array}{c}\text { Diabetes; } \\
\text { Dyslipidemia }\end{array}$ & 451.49 & Kyorin & $\begin{array}{c}\text { Phase II } \\
\text { discontinued }\end{array}$ \\
\hline DSP-8658 & $\begin{array}{l}\text { Dual } \operatorname{PPAR} \alpha / \gamma \\
\text { agonist }\end{array}$ & $\begin{array}{c}\text { Type } 2 \text { diabetes; } \\
\text { Alzheimer's disease }\end{array}$ & unknown & Dainippon Sumitomo & $\begin{array}{c}\text { Phase I } \\
\text { discontinued }\end{array}$ \\
\hline ARH-049020 & PPAR agonists & $\begin{array}{l}\text { Type } 2 \text { diabetes; } \\
\text { Insulin resistance }\end{array}$ & 429.51 & AstraZeneca & $\begin{array}{c}\text { Phase I } \\
\text { discontinued }\end{array}$ \\
\hline LY-510929 & $\begin{array}{c}\text { Dual } \operatorname{PPAR} \alpha / \gamma \\
\text { agonist }\end{array}$ & $\begin{array}{l}\text { Type } 2 \text { diabetes; } \\
\text { Hyperlipidemia }\end{array}$ & 463.55 & Lilly & $\begin{array}{c}\text { Phase I } \\
\text { discontinued }\end{array}$ \\
\hline GSK-376501 & $\operatorname{PPAR} \gamma$ agonist & $\begin{array}{c}\text { Type } 2 \text { diabetes; } \\
\text { Hypercholesterolemia }\end{array}$ & 531.649 & GlaxoSmithKline & $\begin{array}{c}\text { Phase I } \\
\text { discontinued }\end{array}$ \\
\hline $\begin{array}{l}\text { Tetradecylthioacetic } \\
\text { acid }\end{array}$ & $\begin{array}{c}\text { Pan-PPAR agonists; } \\
\text { Lipid Peroxidation } \\
\text { inhibitors }\end{array}$ & $\begin{array}{l}\text { Type } 2 \text { diabetes; } \\
\text { Dyslipidemia }\end{array}$ & 288.49 & $\begin{array}{l}\text { Badische } \\
\text { Anilin-und-Soda-Fabrik }\end{array}$ & $\begin{array}{c}\text { Phase I } \\
\text { discontinued }\end{array}$ \\
\hline
\end{tabular}

The sulfur-substituted fatty acid analog tetradecylthioacetic acid (TTA) is a pan-PPAR activator that reduces plasma lipids and enhances hepatic fatty acid oxidation in rodents [92]. In rats, TTA causes a significant reduction in plasma triacylglycerol accompanied by increased mitochondrial and peroxisomal $\beta$-oxidation in the liver [93,94]. TTA might exert beneficial effects by increasing complete fatty acid oxidation and TAG formation, thereby improving overall energy metabolism and fatty acid handling in T2DM skeletal muscle [95]. However, the development of TTA has been discontinued due to deleterious effects on the heart, including reduced cardiac efficiency, impaired mitochondrial respiratory capacity and reduced functional recovery following ischemia-reperfusion [96]. Cevoglitazar, a dual agonist of PPAR $\alpha / \gamma$, is currently being developed for the treatment of dyslipidemia and obesity associated with T2DM [97]. Cevoglitazar has demonstrated both antiobesity and antidiabetic properties in mice and monkey models of obesity, providing a potential novel approach for the treatment of human obesity, diabetes and related metabolic disorders by using a single small molecule [98]. In phase I trials, the compound was reportedly more efficacious than fenofibrate in lowering lipids and at last report, it was also in phase IIa trials for the treatment of dyslipidemia [99]. However, Novartis (Basel, Swiss) announced that they had terminated the development of cevoglitazar without providing a reason [99]. The dual PPAR $\alpha / \gamma$ ligand MK-0767, also known as KRP-297, was found to have potent insulin-sensitizing and antihyperglycemic activities in a preclinical model of obese T2DM, ob/ob mice $[100,101]$. The effects of the compound on triglyceride and cholesterol levels were assessed in hamster and dog, two species that have previously provided predictive data on the beneficial actions of other drugs, such as fibric acid derivatives and statins, currently used to treat human dyslipidemia [102]. However, MK-0767 has been noted to produce urothelial cancer and hemangiosarcoma in rodents and thus, its development has been discontinued [103]. Sodelglitazar is a panagonist active towards all three PPARs. Sodelglitazar reached phase II clinical development for the treatment of T2DM and metabolic syndrome [104]. However, this research has been discontinued because of serious safety concerns [105]. DSP-8658 is a nonthiazolidinedione compound that markedly improves glucose metabolism and increases $\beta$-cell volume, reduces adipocyte size and ameliorates plasma TG levels in 
diabetic mice [106]. DSP-8658 reached phase I clinical trials by Dainippon Sumitomo for the treatment of Alzheimer's disease and type 2 diabetes. However, this research has been discontinued [58].

In addition, many drugs intended for the treatment of diabetes-associated complications have been terminated at the clinical research stage, including AVE-0847 (phase II, Sanofi), KRP-101 (phase II, Kyorin), ARH-049020 (phase I, AstraZeneca), LY-510929 (phase I, Lilly) and GSK-376501 (phase I, GlaxoSmithKline).

\section{PPAR Ligand Therapeutics in Lipid Metabolism Disorder}

The PPAR family of NRs is implicated in the regulation of lipid homeostasis and represents a valuable therapeutic target for obesity. Obesity, defined as a body mass index (BMI) $\geq 30 \mathrm{~kg} / \mathrm{m}^{2}$, is an international public health issue that affects the quality of life, increases the risk of illness and raises healthcare costs in countries in all parts of the world [107-109]. Obesity is strongly associated with insulin resistance [110], nonalcoholic fatty liver disease (NAFLD)/nonalcoholic steatohepatitis [111], dyslipidemia [112] and atherosclerosis [113]. In this metabolic derangement, PPAR $\alpha$ agonists, mainly fibrates and omega- 3 fatty acids, act as powerful TG-lowering agents. They are used mainly to treat metabolic dyslipidemia [21], which is an abnormal amount of lipids including triglycerides, cholesterol and fat phospholipids in the blood.

\subsection{Dyslipidemia}

Hyperlipidemia, the most common type of dyslipidemia, is a condition of elevated lipid levels and is known to accelerate the process of atherosclerosis, which may prove fatal in the development of various cardiovascular diseases. Increases in lipids, such as LDL, cholesterol and triglycerides, are mainly responsible for hyperlipidemia. The current pharmacotherapy for hyperlipidemia includes statins, niacin, fibric acid derivatives and cholesterol absorption inhibitors [114]. Fibrates, such as PPAR $\alpha$ activators, have been used for decades in the management of combined dyslipidemia [115]. Fibrates can lower triglyceride levels by an average of $36 \%$ and raise levels of small HDL particles [116]. Fibrates increase the production of apolipoprotein AI (apoAI) and AII in the liver, which in turn stimulates HDL production. Triglyceride synthesis is also decreased and lipoprotein lipase activated in response to treatment with fibrates, reducing VLDL synthesis and enhancing its clearance [117]. In addition to fibrates, these approved drugs improve lipid metabolism, as shown in patients with dyslipidemia treated with bezafibrate [118], fenofibrate [119] and ciprofibrate [120] and to a lesser extent in patients treated with gemfibrozil [121]. The approved PPAR ligand drugs for the treatment of dyslipidemia are shown in Table 8.

Clofibrate, the fibric acid derivative, was first approved for use in the United States in 1967 and was the most universally used lipid-lowering drug for many years [122]. However, after the World Health Organization trial found no reduction in overall cardiovascular events and an increase in overall mortality, the use of clofibrate was declined sharply, in part because of cholecystectomy secondary to death [123]. Many fibric acid analogs have been developed since then. Currently, gemfibrozil and fenofibrate are approved for use in the United States; besides bezafibrate and ciprofibrate are available in Europe [124]. Fenofibrate is an oral prodrug that is converted by esterases into its active metabolite, fenofibric acid [125], which is one of the most widely lipid-lowering agent and usually combines with a statin [126]. Fenofibrate has been used commercially under the brand name Tricor $^{\circledR}[127,128]$ but its use is considerably limited because it has very low bioavailability, chiefly under fasting conditions, due to its poor water solubility and lipophilic nature [129]. Trilipix ${ }^{\circledR}$ (choline fenofibrate, ABT-335) is the newest formulation of a fibric acid derivative approved by the FDA. Trilipix $^{\circledR}$ does not require enzymatic cleavage to become active. Instead, it rapidly dissociates to the active form of free fenofibric acid within the gastrointestinal tract and does not undergo first-pass hepatic metabolism [130]. Fenofibric acid has proven to be safe both as a monotherapy and in combination with statins. In addition, long-term trials have shown that treatment with fenofibric acid combined with statins for up to 2 years in patients with mixed dyslipidemia is safe, in that that no 
deaths, rhabdomyolysis, or other serious adverse events were reported [126]. The old and well-known lipid-lowering fibric acid derivative bezafibrate is the first clinically tested pan-PPAR activator with a good safety profile [131]. A clinical study, the Bezafibrate Atherosclerosis Coronary Intervention Trial (BECAIT), has shown that the long-term administration of bezafibrate can slow the rate of progression of atherosclerotic lesions in young male post infarction patients and thus reduce the incidence of coronary events [132]. However, from a biochemical point of view, bezafibrate is a PPAR ligand with a relatively low potency. Gemfibrozil, similar to other fibric acid derivatives, has a wide range of potentially favorable effects on lipoprotein metabolism [133]. The VA High-Density Lipoprotein Intervention Trial (VA-HIT), which was conducted with gemfibrozil, is the first lipid intervention trial to show that raising HDL-C concentrations in persons with established coronary heart disease (CHD) and both a low HDL-C and a low LDL-C level will significantly reduce the incidence of major coronary events [116]. Gemfibrozil increases plasma HDL-C by decreasing cholesteryl ester transfer protein-mediated cholesterol exchange from HDL and by directly stimulating hepatic HDL synthesis and secretion [134]. Ciprofibrate is known to decrease TG and TC levels and increase HDL cholesterol levels in hyperlipidemic patients [135]. However, ciprofibrate raises serum creatinine and lowers the activity of hepatic enzymes in the serum [136]. Pemafibrate (K-877) is a novel member of the selective PPAR $\alpha$ modulator (SPPARM $\alpha$ ) family [137] that was designed to have a higher PPAR $\alpha$ agonistic activity and selectivity than existing PPAR $\alpha$ agonists (such as fibrates) [138]. Pemafibrate exhibits protective antiatherogenic properties in mice by its TG and remnant lipoprotein-lowering effects, its beneficial effects on HDL metabolism and RCT and its anti-inflammatory activity in macrophages and the arterial wall, resulting in reduced atherosclerosis burden [139]. In phase III clinical trials, compared to fenofibrate, pemafibrate has greater PPAR $\alpha$ activation in vitro and lower effects on TGs than fenofibrate. It may become a better choice for patients with metabolic syndrome and T2DM who with residual CV risk [137]. Statins, the favorable agents for lower lipid parameters, combining with fibrates is a better treatment strategy because the two drugs work differently and can complement each other [140,141].The combination of fenofibrate with $20 \mathrm{mg}$ or $40 \mathrm{mg}$ simvastatin was more potent in reducing TG and increasing HDL-C levels than monotherapy with simvastatin or fenofibrate separately [142]. In addition, another drug, pravastatin sodium/fenofibrate, is also on the market for dyslipidemia treatment. However, statin-fibrate combination should be attention due to increasing risk of myopathy and rhabdomyolysis [143].

Table 8. Drugs of PPAR ligands for treatment of dyslipidemia in market.

\begin{tabular}{ccccc}
\hline $\begin{array}{c}\text { Generic } \\
\text { Name }\end{array}$ & Type of PPAR Agonist & Indication & Molecular Weight & Company \\
\hline Clofibrate & PPAR agonists & $\begin{array}{c}\text { Hyperlipidemia } \\
\text { Hypertriglyceridemia } \\
\text { Hypercholesterolemia }\end{array}$ & 242.699 & Pfizer \\
\hline $\begin{array}{c}\text { Fenofibrate; } \\
\text { Fenomax }\end{array}$ & PPAR $\alpha$ agonists & $\begin{array}{l}\text { Hypercholesterolemia } \\
\text { Hypertriglyceridemia }\end{array}$ & 360.834 & Abbvie \\
\hline $\begin{array}{c}\text { Choline } \\
\text { Fenofibrate }\end{array}$ & PPAR $\alpha$ agonists & Hyperlipidemia & 421.918 & Abbvie \\
\hline $\begin{array}{c}\text { Bezafibrate } \\
\text { Pan-PPAR agonists }\end{array}$ & $\begin{array}{l}\text { Hypertriglyceridemia } \\
\text { Mixed hyperlipidemia }\end{array}$ & 361.822 & Unknown \\
\hline Gemfibrozil & PPAR agonists & $\begin{array}{c}\text { Hyperlipidemia; } \\
\text { Ischemic heart disorder }\end{array}$ & 250.338 & Pfizer \\
\hline Ciprofibrate & PPAR agonists & Hyperlipidemia & 289.152 & Unknown \\
\hline Pemafibrate & PPAR $\alpha$ agonists & Dyslipidemia & 490.556 & Kowa \\
\hline
\end{tabular}


Forty years after the introduction of the first fibrate in clinical practice, the exact role of these pharmacologic compounds remains ill-defined [144]. Hence, there are still novel PPAR agonists intended for dyslipidemia treatment in the clinical research stage, as shown in Table 9.

Table 9. Drugs of PPAR ligands for treatment of dyslipidemia in clinical stage.

\begin{tabular}{|c|c|c|c|c|c|}
\hline Generic Name & Type of PPAR Agonist & Indication & $\begin{array}{l}\text { Molecular } \\
\text { Weight }\end{array}$ & Company & $\begin{array}{l}\text { Development } \\
\text { Status }\end{array}$ \\
\hline Elafibranor & Dual PPAR $\alpha / \delta$ agonist & $\begin{array}{l}\text { Non-alcoholic fatty } \\
\text { liver disease (NAFLD); } \\
\text { Dyslipidemia; } \\
\text { Type } 2 \text { diabetes }\end{array}$ & 384.49 & Genfit & Phase III active \\
\hline Icosabutate & $\begin{array}{c}\text { PPAR agonists; } \\
\text { Cholesterol ester transfer } \\
\text { protein inhibitors }\end{array}$ & Hypertriglyceridemia & 374.565 & BASF & Phase II active \\
\hline ZYH-7 & PPAR $\alpha$ agonists & Dyslipidemia & unknown & Zydus cadila & Phase II active \\
\hline CER-002 & PPAR $\delta$ agonists & Dyslipidemia & unknown & $\begin{array}{l}\text { Nippon } \\
\text { Chemiphar }\end{array}$ & Phase I active \\
\hline GSK-625019 & PPAR agonists & $\begin{array}{l}\text { Metabolic Syndrome X; } \\
\text { Type } 2 \text { diabetes }\end{array}$ & unknown & GlaxoSmithKline & Phase I Pending \\
\hline KD-3010 & PPAR $\alpha$ agonists & $\begin{array}{l}\text { Obesity; Diabetes; } \\
\text { Dyslipidemia }\end{array}$ & 670.72 & Kalypsys & Phase I Pending \\
\hline
\end{tabular}

Nonalcoholic steatohepatitis (NASH) defines a subgroup of nonalcoholic fatty liver disease where liver steatosis coexists with hepatic cell injury (apoptosis and hepatocyte ballooning) and inflammation [145]. It occurs in close association with obesity, T2DM and cardiometabolic conditions that define the metabolic syndrome [146]. Elafibranor is a selective dual agonist against PPAR $\alpha / \delta$ that has demonstrated efficacy in disease models of NAFLD/NASH and liver fibrosis [147]. Elafibranor exerts its major effects through the transcriptional regulation of key genes involved in hepatic lipid and glucose metabolism but also modulates hepatic inflammation and collagen turnover [147]. In phase III trials, elafibranor consistently improved plasma lipids and glucose homeostasis, peripheral and hepatic insulin resistance and liver inflammatory markers in dyslipidemic, prediabetic and T2DM patients $[148,149]$. Three prescription OM3-FAs (eicosapentaenoic acid (EPA) and docosahexaenoic acid (DHA)) have been approved for the management of severe hyperlipidemia [150]. Icosabutate, a first-in-class synthetic, structurally enhanced omega- 3 fatty acid derivative, has PPAR $\alpha$ activity but with potentially important differences from the fibrates and OM3-FAs. Preclinical observations proved to be consistent with results from an exploratory phase $\mathrm{Ib}$ study in hypercholesterolemic subjects, in which icosabutate significantly reduced TGs, ApoC3 and low-density lipoprotein cholesterol (LDL-C) [151]. KD-3010, a dual PPAR $\beta / \delta$ agonist, is under development by Kalypsys. Kalypsys has demonstrated activity in animal models of nonalcoholic steatohepatitis, high fat diet-induced obesity and the ob/ob mouse. Phase Ia safety/tolerability studies have been completed and a phase $\mathrm{Ib}$ dose-range study was begun in 2007 [152]. In addition, there are many drugs at the clinical research stage, including ZYH-7 (phase II, Zydus Cadila), CER-002 (phase I, Nippon Chemiphar) and GSK-625019 (phase I, GlaxoSmithKline).

There are also PPAR ligand drugs intended for the treatment of dyslipidemia whose development was terminated in the clinical research stage. We summarize these drugs as follows (Table 10).

The treatment of mixed dyslipidemia is fraught with difficulty because of the need to reduce LDL-C and TG levels while trying to elevate HDL-C levels. For this purpose, combination drug therapy is often the only effective option. Unfortunately, the drug combinations utilized for mixed dyslipidemia potentially increase the risk for adverse events. Rosuvastatin, the newest in its class, is the most potent statin currently available and provides significant reductions in LDL-C and TG and elevations in HDL-C. When used in combination to treat mixed dyslipidemia, rosuvastatin and fenofibrate or rosuvastatin and fenofibric acid demonstrate beneficial effects in this patient population and are well tolerated with no increased risk of adverse events [153]. In addition, many drugs have been terminated 
at the clinical research stage, including GW-501516 (phase II, GlaxoSmithKline), GFT 14 (phase II, Genfit), GW-544 (phase I, GlaxoSmithKline), DFR-11605 (phase I, Dr Reddys Laboratories), MP-136 (phase I, Mitsubishi Tanabe Pharma), DRF-10945 (phase I, Dr Reddys Laboratories), NS-220 (phase I, Nippon Shinyaku Pharma) and F-16482 (phase I, Pierre Fabre).

Table 10. Drugs of PPAR ligands for treatment of dyslipidemia discontinued in clinical stage.

\begin{tabular}{cccccc}
\hline Generic Name & $\begin{array}{c}\text { Type of PPAR } \\
\text { Agonist }\end{array}$ & Indication & $\begin{array}{c}\text { Molecular } \\
\text { Weight }\end{array}$ & Company & $\begin{array}{c}\text { Development } \\
\text { Status }\end{array}$ \\
\hline GW-501516 & PPAR $\delta$ agonists & Hyperlipidemia & 453.494 & GlaxoSmithKline & $\begin{array}{c}\text { Phase II } \\
\text { discontinued }\end{array}$ \\
\hline GFT 14 & PPAR $\alpha$ agonists & Dyslipidemia & unknown & Genfit & $\begin{array}{c}\text { Phase II } \\
\text { discontinued }\end{array}$ \\
\hline GW-544 & $\begin{array}{c}\text { Dual PPAR } \alpha / \gamma \\
\text { agonist }\end{array}$ & Hyperlipidemia & 510.58 & $\begin{array}{c}\text { GlaxoSmithKline } \\
\text { (Originator)Ligand }\end{array}$ & $\begin{array}{c}\text { Phase I } \\
\text { discontinued }\end{array}$ \\
\hline DFR-11605 & PPAR agonists & Obesity & unknown & $\begin{array}{c}\text { Dr Reddys Laboratories } \\
\text { (Originator)Perlecan }\end{array}$ & $\begin{array}{c}\text { Phase I } \\
\text { discontinued }\end{array}$ \\
\hline MP-136 & PPAR $\alpha$ agonists & Dyslipidemia & unknown & $\begin{array}{c}\text { Mitsubishi Tanabe Pharma } \\
\text { Phase I } \\
\text { discontinued }\end{array}$ \\
\hline DRF-10945 & PPAR $\alpha$ agonists & $\begin{array}{c}\text { Lipid metabolism } \\
\text { disorders }\end{array}$ & unknown & $\begin{array}{c}\text { Dr Reddys Laboratories } \\
\text { (Originator)Perlecan }\end{array}$ & $\begin{array}{c}\text { Phase I } \\
\text { discontinued }\end{array}$ \\
\hline NS-220 & PPAR $\alpha$ agonists & $\begin{array}{c}\text { Lipid metabolism } \\
\text { disorders }\end{array}$ & 373.449 & $\begin{array}{c}\text { Nippon Shinyaku Pharma } \\
\text { Phase I } \\
\text { discontinued }\end{array}$ \\
\hline F-16482 & PPAR modulator & $\begin{array}{c}\text { Metabolic } \\
\text { Syndrome X }\end{array}$ & unknown & PIERRE FABRE & $\begin{array}{c}\text { Phase I } \\
\text { discontinued }\end{array}$ \\
\hline
\end{tabular}

\subsection{Cardiovascular Diseases (CVDs)}

Dyslipidemia is one of the major risk factors for CVD and plasma TG levels are a strong predictor of CVD [154]. CVDs are the leading cause of mortality and morbidity, accounting for $31 \%$ of all deaths worldwide. Of all deaths due to CVD, approximately $80 \%$ are due to CHD or stroke. Numerous studies have shown that blood cholesterol-lowering therapy reduces the occurrence of atherosclerotic cardiovascular disease (ASCVD) [155]. 3-Hydroxy-3-methyl-glutaryl-coenzyme A reductase (HMG-CoA) inhibitors or statins have demonstrated a significant reduction in CVD risk in a large number of landmark trials [156]. However, $70 \%$ of risk remains even after the treatment of high LDL-C by statins [157]. To further reduce this risk, fibrates are recommended to manage elevated TG and low HDL-C levels.

Hence, dual therapy of statins with fibrates can improve triglyceride and HDL-C levels more than monotherapy with equivalent dose statins, as shown in Table 11.

Table 11. Drugs of PPAR ligands for treatment of cardiovascular disease (CVD).

\begin{tabular}{cccccc}
\hline Generic Name & $\begin{array}{c}\text { Type of PPAR } \\
\text { Agonist }\end{array}$ & Indication & $\begin{array}{c}\text { Molecular } \\
\text { Weight }\end{array}$ & Company & $\begin{array}{c}\text { Development } \\
\text { Status }\end{array}$ \\
\hline $\begin{array}{c}\text { Gemcabene } \\
\text { Calcium }\end{array}$ & PPAR agonists & Hypercholesterolemia & 340.473 & $\begin{array}{c}\text { Gemphire } \\
\text { Therapeutics }\end{array}$ & Phase II active \\
\hline KRP-105 & PPAR $\alpha$ agonists & Hypercholesterolemia & unknown & Kyorin & $\begin{array}{c}\text { Phase I } \\
\text { discontinued }\end{array}$ \\
\hline
\end{tabular}

Pitavastatin is a competitive inhibitor of HMG-CoA reductase, the enzyme that stimulates the production of mevalonate, which is the rate-determining step in cholesterol biosynthesis [158]. The use of drugs that inhibit this enzyme has been associated with reductions in TC and LDL-C in a dose-dependent manner [159]. The co-administration of fenofibrate with pitavastatin for 7 days was found to be safe, well tolerated and without clinically significant PK interactions [160]. Furthermore, low doses of pitavastatin and fenofibrate were both effective in decreasing sd-LDL-C concentration 
and reduction [161]. In addition to the co-administration of fibrate with stain, there are other drugs in the clinical research stage. Gemcabene calcium is a small molecule, the monocalcium salt of a dialkyl ether dicarboxylic acid with the chemical name 6,6'-oxybis(2,2-dimethylhexanoic acid) monocalcium salt and is currently in late-stage clinical development. In rodents, gemcabene showed varying targets, including apoC-III, apoA-I and peroxisomal enzymes, which are considered to be regulated via PPAR gene activation, suggesting a PPAR-mediated mechanism of action for the observed hypolipidemic effects observed in rodents and humans [162]. By inhibiting interleukin-1 beta (IL-1 $\beta$ ) -induced inflammation and CRP production and resulting in improvements in CVD events through inhibiting IL-1 $\beta$, canakinumab, in the Canakinumab Anti-inflammatory Thrombosis Outcomes Study (CANTOS) study [163] and gemcabene have shown hypolipidemic and anti-inflammatory properties, in addition to LDL lowering activity, which offers an added benefit to CVD patients [164]. KRP-105, developed by Kyorin, is a highly selective PPAR $\alpha$ agonist. In addition to improving the lipid metabolism, KRP-105 increased adiponectin, reduced leptin and suppressed weight gain in animal models, suggesting its potential as a unique antidyslipidemia agent. However, KRP-105 was discontinued from development as part of the company's R \& D strategy [165].

\section{PPAR Ligand Therapeutics in Other Diseases}

PPARs are not only drug targets of glucose and lipid metabolism but also can be used to treat other diseases, such as primary biliary cholangitis, gout, cancer, $\mathrm{AD}$ and ulcerative colitis. Here, we summarize the PPAR ligand drugs for the treatment of other diseases in the clinical research stage (Table 12).

Functional studies of PPAR $\delta$ are still in its infancy and there are increasing evidences that ubiquitously expressed PPAR $\delta$ has multiple effects and can control a variety of physiological processes, mainly including lipid and lipoprotein metabolism regulation [166,167], insulin sensitivity [168], cardiac function [169], epidermal biology [170], neuroprotection [171] and gastrointestinal tract function and disease [172] Primary biliary cholangitis is a progressive cholangitic liver disease that, if untreated, progresses to cirrhosis and death or liver transplantation [173]. Two types of drugs are currently approved for the medical treatment of primary biliary cholangitis (PBC), ursodeoxycholic acid and obeticholic acid [174] but both have certain adverse effects [174,175]. Seladelpar, a selective PPAR $\delta$ agonist, is a new therapy for PBC through regulating the cholesterol transporter ABCG5/ABCG8 [176]. Seladelpar appeared safe and well tolerated with no specific adverse reaction definitively associated with the drug [176]. Seladelpar reduces the number of macrophages, fibrosis and other markers of stellate cell activity in a mouse model [177]. In patients with mixed dyslipidemia [176] or homozygous familial hypercholesterolemia, seladelpar reduced LDL-C and induced sustained decreases in biochemical markers of cholestasis such as alkaline phosphatase, $\gamma$-glutamyl transpeptidase (GGT) and total bilirubin [178]. In phase III trials, seladelpar treatment normalized alkaline phosphatase levels but this treatment was associated with grade 3 increases in aminotransferases and the study was stopped early. Accordingly, the effects of seladelpar at lower doses should be explored.

Gout is the most common cause of inflammatory arthritis and has a major impact on quality of life $[179,180]$. Chronic hyperuricemia, the biochemical signature of the disease, leads to the deposition of urate crystals in articular structures and the disruption of these crystals is believed to trigger flares [181]. Arhalofenate, a selective partial PPAR $\gamma$ modulator, is a single enantiomer of halofenate and developed as a lipid-lowering agent [182,183]. Recently, arhalofenate was proven to be a uricosuric drug that lowers serum UA by blocking its reabsorption by the inhibition of URAT1 [184] in the proximal tubules of the kidney. Additionally, arhalofenate has been suggested to exert a potent anti-inflammatory effect [184]. In the phase IIb study, arhalofenate at a dosage of $800 \mathrm{mg}$ decreased gout flares significantly compared to allopurinol at a dosage of $300 \mathrm{mg}$ [184]. Another dual $\operatorname{PPAR} \alpha / \gamma$ agonist, oxeglitazar, whose development was halted in phase I clinical trials, is also used for gout treatment. 
Table 12. Drugs of PPAR ligands for treatment of other diseases in clinical stage.

\begin{tabular}{|c|c|c|c|c|c|}
\hline Generic Name & Type of PPAR Agonist & Indication & Molecular Weight & Company & Development Status \\
\hline $\begin{array}{l}\text { Seladelpar lysine } \\
\text { dihydrate }\end{array}$ & PPARס agonists & Primary biliary cirrhosis & 626.685 & $\begin{array}{l}\text { Janssen (Originator) } \\
\text { CymaBay Therapeutics }\end{array}$ & Phase III active \\
\hline Arhalofenate & Partial PPAR $\gamma$ modulators & Chronic gout & 415.793 & CymaBay Therapeutics & Phase II active \\
\hline T3D-959 & Dual agonist of PPAR $\delta / \gamma$ & Alzheimer's disease & 443.47 & DARA BioSciences & Phase II active \\
\hline $\begin{array}{c}\text { Efatutazone } \\
\text { hydrochloride }\end{array}$ & Selectively activates PPAR $\gamma$ & $\begin{array}{c}\text { Thyroid cancer; } \\
\text { Non-small cell lung } \\
\text { cancer; Colorectal cancer }\end{array}$ & 593.52 & Daiichi Sankyo & Phase II Pending \\
\hline IVA-337 & PPAR agonists & Systemic sclerosis & 434.92 & Abbvie(Originator)Inventiva & Phase II active \\
\hline Fonadelpar & PPAR agonists & Corneal disorders & 504.524 & Senju Pharmaceuticals & Phase II active \\
\hline OMS-403 & $\operatorname{PPAR} \gamma$ agonists & $\begin{array}{l}\text { Opioid abuse Smoking } \\
\text { cessation }\end{array}$ & unknown & Omeros & Phase II active \\
\hline $\begin{array}{l}\text { 10-Nitrooctadec-9-enoic } \\
\text { acid }\end{array}$ & $\begin{array}{l}\text { PPAR } \gamma \text { ligands; Transcription } \\
\text { factor modulators; } \\
\text { Inflammation mediator } \\
\text { modulators }\end{array}$ & $\begin{array}{l}\text { Acute kidney injury Renal } \\
\text { failure }\end{array}$ & 327.465 & Complexa & Phase I active \\
\hline GED-0507-34 & PPAR modulator & $\begin{array}{c}\text { Inflammatory bowel } \\
\text { disease }\end{array}$ & unknown & Giuliani & Phase I active \\
\hline Macuneos & PPAR $\alpha$ agonists & $\begin{array}{c}\text { Age-related macular } \\
\text { degeneration }\end{array}$ & unknown & Biophytis & Phase I active \\
\hline MA-0211 & PPAR $\delta$ modulators & $\begin{array}{l}\text { Duchenne muscular } \\
\text { dystrophy }\end{array}$ & unknown & Astellas & Phase I active \\
\hline Oxeglitazar & Dual PPAR $\alpha / \gamma$ agonist & Gout & 314.381 & Merck Serono & Phase I Pending \\
\hline Etalocib sodium & $\begin{array}{c}\text { PPAR } \gamma \text { agonists; } \\
\text { 5-Lipoxygenase inhibitor; } \\
\text { Leukotriene B4 receptor } \\
\text { antagonist }\end{array}$ & $\begin{array}{l}\text { Pancreatic cancer; } \\
\text { Non-small cell lung } \\
\text { cancer }\end{array}$ & 566.601 & Lilly(Originator)Vernalis & Phase II discontinued \\
\hline
\end{tabular}


Over the course of several decades of research, evidence has emerged that Alzheimer's disease (AD) is quite complex and is associated with a multitude of cellular, biochemical and molecular abnormalities [185]. In fact, AD could be regarded as a brain form of diabetes, since insulin resistance and deficiency develop early and progress with the severity of neurodegeneration [186]. T3D-959 is a small-molecule dual agonist of PPAR $\delta / \gamma[185]$ and has clear effects that preserve spatial learning and memory in an established experimental model of sporadic AD [186]. In a phase Ila trial, T3D-959 significantly improved motor performance and preserved both cortical and normalized white matter structure via the agonism of PPAR $\delta$ and PPAR $\gamma$ in AD model rats [186].

Lung cancer is one of the highest cancer deaths worldwide and more than $60 \%$ of lung cancer patients are already in an incurable stage of diagnosis $[187,188]$. For many years, platinum-based doublet chemotherapy has become the most common treatment for patients with advanced non-small cell lung cancer (NSCLC) [189]. However, excessively toxic chemotherapy is also a concern for the public. PPAR $\gamma$ has been shown to possess antitumor properties in preclinical models of human cancers, including NSCLC $[190,191]$. Efatutazone is a novel third-generation thiazolidinedione that selectively activates PPAR $\gamma$-mediated transcription with little effect on other PPAR subtypes [192]. Efatutazone is at least 50 times more potent than rosiglitazone and 500 times more potent than troglitazone for PPAR response element activation and the inhibition of cancer cell growth [193]. In a phase I study, efatutazone demonstrated acceptable tolerability with evidence of disease control in patients with advanced malignancies [192]. In addition, efatutazone inhibits the proliferation of human pancreatic and anaplastic thyroid tumor-cell cultures [194]. Daiichi Sankyo (originator of efatutazone hydrochloride) reinitiated enrolment in a phase II trial of efatutazone for the treatment of thyroid cancer. Another agonist of PPAR $\gamma$, etalocib sodium (LY293111), which is a biphenyl-substituted diaryl ether carboxylic acid, is also a potential agent for the medical treatment of NSCLC [195]. In a phase I study, oral LY293111 was generally well tolerated, with a recommended phase II dose of $600 \mathrm{mg}$ orally twice daily [196]. LY has also been found to inhibit pancreatic cancer cell lines as well as human pancreatic xenografts [197]. The development of LY-293111 for NSCLC treatment has subsequently been discontinued; however, clinical research on its effect on pancreatic and other cancers are ongoing.

Recent epidemiological data show that the incidence and prevalence of ulcerative colitis (UC) are increasing in many parts of the world [198]. PPAR $\gamma$ has been shown to be expressed in macrophages [199], dendritic cells (DCs) [200] and T and B lymphocytes [200]. More importantly, rosiglitazone was shown to be effective in the treatment of mild to moderately active UC [201]. (R)-(-)-GED-0507-34 has demonstrated 100- to 150-fold higher PPAR $\gamma$ activation than 5-ASA in vitro using Caco-2 cells transfected with PPRE-Luc reporter system [202]. None of these deleterious events has been observed with the new PPAR $\gamma$ modulator GED-0507-34, even when used at high concentrations during toxicological studies performed in rats, dogs and rabbits and no side effects were observed in the phase I study performed in 24 healthy subjects [202]. This new molecule is currently in phase II of clinical trials [203]. IVA337, the pan-PPAR agonist, is a therapeutic agent for systemic sclerosis through improving inflammatory and fibrosis [204]. There are many drugs used in the treatment of other diseases, including OMS-403 (phase II, Opioid abuse, Smoking cessation), fonadelpar (phase II, Corneal disorders), IVA-337 (phase II, Systemic sclerosis), macuneos (phase I, Age-related macular degeneration), MA-0211 (phase I, Duchenne's muscular dystrophy).

\section{Discussion}

Metabolic abnormalities, including T2DM, dyslipidemia, NAFLD and CVD, are a worldwide epidemic that seriously endangers global health. Considering the wide range of roles involved in energy homeostasis and cell proliferation/apoptosis, PPAR agonists are suggested for the treatment of metabolic disorders. In this study, we comprehensively summarized the roles of PPAR synthetic ligands in current clinical applications or studies for the treatment of T2DM, DN, obesity, CVDs, MS, $\mathrm{AD}$, gout, cancer, PBC, UC et al., as shown in Figure 2. 


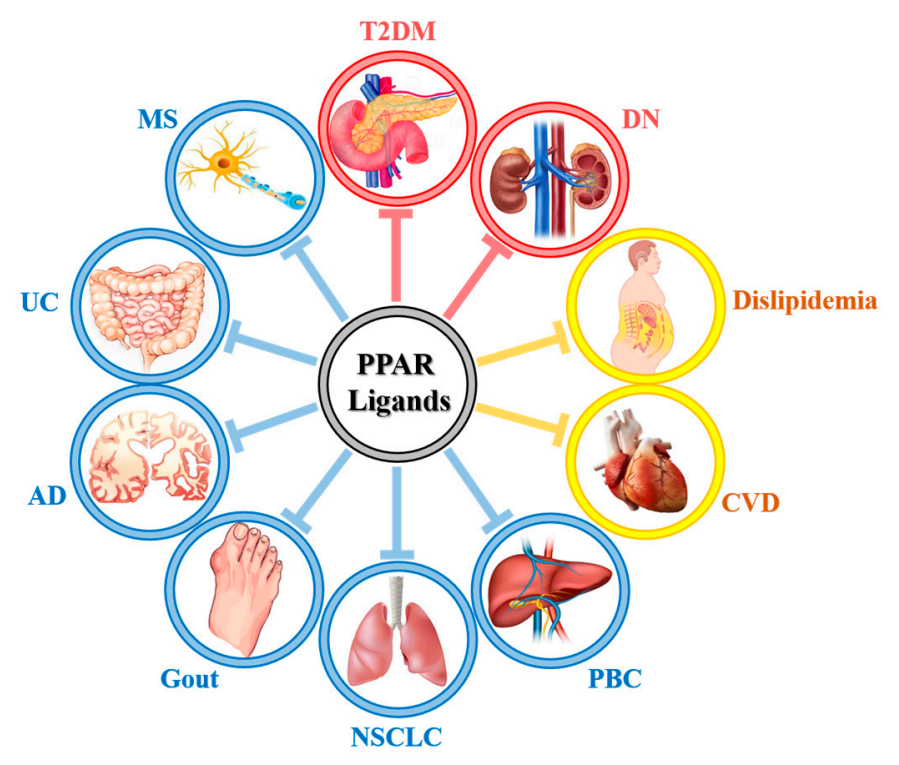

Figure 2. Concept map of the PPAR ligands in various kinds of diseases. T-bar: inhibition.

Diabetes treatment drugs represented by TZDs, which mainly activate PPAR $\gamma$, have received widespread attention and are focuses for drug development. Over the past decades, in addition to the eight existing TZD drugs that have been approved and used in clinical treatment, many drugs are still in clinical studies or have even been discontinued. The use of TZDs for diabetes treatment in humans has been limited by side effects, including edema, weight gain and worsening of CHF. Thus, an increasing number of partial PPAR $\gamma$ agonists or SSPARMs, such as INT131 and MK0533, have been developed to reduce the side effects while improving insulin sensitivity. In a recent study, we reported that DBZ (danshensu bingpian zhi), a putative PPAR $\gamma$ agonist, simultaneously prevented HFD-induced obesity-related metabolic syndrome and gut dysbiosis. It also has antiatherosclerotic effects that involve inflammation suppression and the promotion of reverse cholesterol transport through concurrent partial activation of both PPAR $\gamma$ and LXRs $[4,205,206]$. Drugs for treating dyslipidemia via activating PPAR $\alpha$, especially represented by fibrates, are also widely used. Fibrate decreases the level of triglyceride-rich lipoproteins in serum by increasing the gene expression involved in fatty acid- $\beta$-oxidation and a decrease in apolipoprotein C-III gene expression [207]. Furthermore, PPAR $\alpha$ agonists can increase the stability of atherosclerotic plaques and reduce the accumulation of hepatic fat accumulation, leading the party to NASH/NAFLD and reducing the risk of CVD. PPAR $\alpha$ agonists have few adverse effects but do generally increase the plasma levels of homocysteine and creatinine, which must also be emphasized [208]. PPAR $\delta$ is ubiquitously expressed and a target for management by the different components of metabolic syndrome. Clinical trials on selected PPAR $\delta$ agonists have assessed both metabolic and vascular outcomes and no severe side effects have been reported to date, except for GW1516, which induced cancer in several organs in rodents [209]. Any differential mechanism of PPAR $\delta$ action in different tissues should be explored in order to develop new PPAR $\delta$ agonists with improved efficacy and safety. In addition to modulating lipid and glucose metabolism, PPAR agonists play significant roles in several diseases, including primary biliary cholangitis, gout, AD, non-small cell lung cancer and UC.

Currently used agonists are still at a relatively preliminary stage, the potency is weak (as is the case for PPAR $\alpha$ ), or there are many side effects (such as in PPAR $\gamma$ ). In the past decade, increasing numbers of compounds have been developed, including dual PPAR agonists $(\operatorname{PPAR} \alpha / \gamma, \operatorname{PPAR} \alpha / \delta$ and $\operatorname{PPAR} \delta / \gamma)$ and pan-PPAR agonists or selective modulators. For example, clofibric acid and fenofibric acid are dual activators of PPAR $\alpha$ and PPAR $\gamma$, with a selectivity to PPAR $\gamma$ of about 10-fold. In addition, bezafibrate, another fibric acid that activates all three PPAR subtypes $(\alpha, \gamma$ and $\delta)$, has a broader role [131]. 
Unfortunately, the development of diverse dual PPAR agonists has not met with the anticipated success. Their development has thus far been halted in late-phase clinical trials because of reported side effects, such as increased cardiovascular risk (muraglitazar), carcinogenicity (ragaglitazar and MK-767), liver toxicity (imiglitazar) and renal injury (tesaglitazar) [210]. In this article, we summarize the current PPAR ligands in clinical drug discovery and development. We hope that more powerful dual PPAR agonists or pan-PPAR agonists will be highly effective in a clinical setting of patients with coexisting relevant lipid and glucose metabolism disorders.

Acknowledgments: This study was supported by grants from National Natural Science Foundation of China (Nos. 31571164 and 31271207 to Y.G. Zhai). We thank Jingwei Xu for guiding drawing of PPARs' 3D structure and Nature Research Editing Service for language editing.

Conflicts of Interest: The authors declare no conflict of interest.

\section{References}

1. Derosa, G.; Sahebkar, A.; Maffioli, P. The role of various peroxisome proliferator-activated receptors and their ligands in clinical practice. J. Cell. Physiol. 2018, 233, 153-161. [CrossRef] [PubMed]

2. Grygiel-Gorniak, B. Peroxisome proliferator-activated receptors and their ligands: Nutritional and clinical implications-A review. Nutr. J. 2014, 13, 17. [CrossRef] [PubMed]

3. Lagana, A.S.; Vitale, S.G.; Nigro, A.; Sofo, V.; Salmeri, F.M.; Rossetti, P.; Rapisarda, A.M.; La Vignera, S.; Condorelli, R.A.; Rizzo, G.; et al. Pleiotropic actions of peroxisome proliferator-activated receptors (PPARs) in dysregulated metabolic homeostasis, inflammation and cancer: Current evidence and future perspectives. Int. J. Mol. Sci. 2016, 17, 999. [CrossRef] [PubMed]

4. Xu, P.; Zhai, Y.; Wang, J. The role of PPAR and its cross-talk with car and lxr in obesity and atherosclerosis. Int. J. Mol. Sci. 2018, 19, 1260. [CrossRef] [PubMed]

5. Amber-Vitos, O.; Chaturvedi, N.; Nachliel, E.; Gutman, M.; Tsfadia, Y. The effect of regulating molecules on the structure of the PPAR-RXR complex. Biochim. Biophys. Acta 2016, 1861, 1852-1863. [CrossRef] [PubMed]

6. Echeverria, F.; Ortiz, M.; Valenzuela, R.; Videla, L.A. Long-chain polyunsaturated fatty acids regulation of PPARs, signaling: Relationship to tissue development and aging. Prostaglandins Leukotrienes Essent. Fatty Acids 2016, 114, 28-34. [CrossRef] [PubMed]

7. Glatz, J.F.; Luiken, J.J. From fat to fat (cd36/sr-b2): Understanding the regulation of cellular fatty acid uptake. Biochimie 2017, 136, 21-26. [CrossRef] [PubMed]

8. Nakamura, M.T.; Yudell, B.E.; Loor, J.J. Regulation of energy metabolism by long-chain fatty acids. Prog. Lipid Res. 2014, 53, 124-144. [CrossRef] [PubMed]

9. Marcus, S.L.; Miyata, K.S.; Zhang, B.; Subramani, S.; Rachubinski, R.A.; Capone, J.P. Diverse peroxisome proliferator-activated receptors bind to the peroxisome proliferator-responsive elements of the rat hydratase/dehydrogenase and fatty acyl-coa oxidase genes but differentially induce expression. Proc. Natl. Acad. Sci. USA 1993, 90, 5723-5727. [CrossRef] [PubMed]

10. Zhang, B.; Marcus, S.L.; Miyata, K.S.; Subramani, S.; Capone, J.P.; Rachubinski, R.A. Characterization of protein-DNA interactions within the peroxisome proliferator-responsive element of the rat hydratase-dehydrogenase gene. J. Biol. Chem. 1993, 268, 12939-12945. [PubMed]

11. Tontonoz, P.; Hu, E.; Graves, R.A.; Budavari, A.I.; Spiegelman, B.M. MPPAR gamma 2: Tissue-specific regulator of an adipocyte enhancer. Genes Dev. 1994, 8, 1224-1234. [CrossRef] [PubMed]

12. Tontonoz, P.; Hu, E.; Devine, J.; Beale, E.G.; Spiegelman, B.M. PPAR gamma 2 regulates adipose expression of the phosphoenolpyruvate carboxykinase gene. Mol. Cell. Biol. 1995, 15, 351-357. [CrossRef] [PubMed]

13. Yan, S.; Yang, X.F.; Liu, H.L.; Fu, N.; Ouyang, Y.; Qing, K. Long-chain acyl-coa synthetase in fatty acid metabolism involved in liver and other diseases: An update. World J. Gastroenterol. 2015, 21, 3492-3498. [CrossRef] [PubMed]

14. Dubois, V.; Eeckhoute, J.; Lefebvre, P.; Staels, B. Distinct but complementary contributions of PPAR isotypes to energy homeostasis. J. Clin. Investig. 2017, 127, 1202-1214. [CrossRef] [PubMed]

15. Neels, J.G.; Grimaldi, P.A. Physiological functions of peroxisome proliferator-activated receptor beta. Physiol. Rev. 2014, 94, 795-858. [CrossRef] [PubMed] 
16. Cronet, P.; Petersen, J.F.; Folmer, R.; Blomberg, N.; Sjoblom, K.; Karlsson, U.; Lindstedt, E.L.; Bamberg, K. Structure of the PPARalpha and -gamma ligand binding domain in complex with az 242; ligand selectivity and agonist activation in the PPAR family. Structure 2001, 9, 699-706. [CrossRef]

17. Xu, H.E.; Lambert, M.H.; Montana, V.G.; Parks, D.J.; Blanchard, S.G.; Brown, P.J.; Sternbach, D.D.; Lehmann, J.M.; Wisely, G.B.; Willson, T.M.; et al. Molecular recognition of fatty acids by peroxisome proliferator-activated receptors. Mol. Cell 1999, 3, 397-403. [CrossRef]

18. Gampe, R.T., Jr.; Montana, V.G.; Lambert, M.H.; Miller, A.B.; Bledsoe, R.K.; Milburn, M.V.; Kliewer, S.A.; Willson, T.M.; Xu, H.E. Asymmetry in the PPARgamma/RXRalpha crystal structure reveals the molecular basis of heterodimerization among nuclear receptors. Mol. Cell 2000, 5, 545-555. [CrossRef]

19. Tan, C.K.; Zhuang, Y.; Wahli, W. Synthetic and natural peroxisome proliferator-activated receptor (PPAR) agonists as candidates for the therapy of the metabolic syndrome. Expert Opin. Ther. Targets 2017, 21, 333-348. [CrossRef] [PubMed]

20. Gross, B.; Pawlak, M.; Lefebvre, P.; Staels, B. PPARs in obesity-induced t2dm, dyslipidaemia and nafld. Nat. Rev. Endocrinol. 2017, 13, 36-49. [CrossRef] [PubMed]

21. Botta, M.; Audano, M.; Sahebkar, A.; Sirtori, C.R.; Mitro, N.; Ruscica, M. PPAR agonists and metabolic syndrome: An established role? Int. J. Mol. Sci. 2018, 19, 1197. [CrossRef] [PubMed]

22. DePaoli, A.M.; Higgins, L.S.; Henry, R.R.; Mantzoros, C.; Dunn, F.L.; Group, I.N.T.S. Can a selective PPARgamma modulator improve glycemic control in patients with type 2 diabetes with fewer side effects compared with pioglitazone? Diabetes Care 2014, 37, 1918-1923. [CrossRef] [PubMed]

23. Janani, C.; Ranjitha Kumari, B.D. PPAR gamma gene-A review. Diabetes Metab. Syndr. 2015, 9, 46-50. [CrossRef] [PubMed]

24. Koster, I.; Huppertz, E.; Hauner, H.; Schubert, I. Costs of diabetes mellitus (codim) in germany, direct per-capita costs of managing hyperglycaemia and diabetes complications in 2010 compared to 2001. Exp. Clin. Endocrinol. Diabetes 2014, 122, 510-516. [CrossRef] [PubMed]

25. Shah, A.D.; Langenberg, C.; Rapsomaniki, E.; Denaxas, S.; Pujades-Rodriguez, M.; Gale, C.P.; Deanfield, J.; Smeeth, L.; Timmis, A.; Hemingway, H. Type 2 diabetes and incidence of cardiovascular diseases: A cohort study in 1.9 million people. Lancet Diabetes Endocrinol. 2015, 3, 105-113. [CrossRef]

26. Chung, J.W.; Hartzler, M.L.; Smith, A.; Hatton, J.; Kelley, K. Pharmacological agents utilized in patients with type-2 diabetes: Beyond lowering a1c. P \& T 2018, 43, 214-227.

27. Yasmin, S.; Jayaprakash, V. Thiazolidinediones and PPAR orchestra as antidiabetic agents: From past to present. Eur. J. Med. Chem. 2017, 126, 879-893. [CrossRef] [PubMed]

28. Investigators, D.T.; Gerstein, H.C.; Yusuf, S.; Bosch, J.; Pogue, J.; Sheridan, P.; Dinccag, N.; Hanefeld, M.; Hoogwerf, B.; Laakso, M.; et al. Effect of rosiglitazone on the frequency of diabetes in patients with impaired glucose tolerance or impaired fasting glucose: A randomised controlled trial. Lancet 2006, 368, 1096-1105.

29. Li, Y.; Zhang, Y.; Li, X.; Shi, L.; Tao, W.; Shi, L.; Yang, M.; Wang, X.; Yang, Y.; Yao, Y. Association study of polymorphisms in mirnas with $\mathrm{t} 2 \mathrm{dm}$ in chinese population. Int. J. Med. Sci. 2015, 12, 875-880. [CrossRef] [PubMed]

30. Shaikh, S.; Muneera, M.S.; Thusleem, O.A.; Tahir, M.; Kondaguli, A.V.; Ruckmani, K. Development and validation of a selective online dissolution method for rosiglitazone maleate. J. Chromatogr. Sci. 2007, 45, 311-314. [CrossRef] [PubMed]

31. Kahn, B.B.; McGraw, T.E. Rosiglitazone, PPARgamma, and type 2 diabetes. N. Engl. J. Med. 2010, 363, 2667-2669. [CrossRef] [PubMed]

32. Mitka, M. Panel recommends easing restrictions on rosiglitazone despite concerns about cardiovascular safety. JAMA 2013, 310, 246-247. [CrossRef] [PubMed]

33. Tzanavaras, P.D.; Verdoukas, A.; Themelis, D.G. Development and validation of a flow-injection assay for dissolution studies of the anti-depressant drug venlafaxine. Anal. Sci. 2005, 21, 1515-1518. [CrossRef] [PubMed]

34. Aronoff, S.; Rosenblatt, S.; Braithwaite, S.; Egan, J.W.; Mathisen, A.L.; Schneider, R.L. Pioglitazone hydrochloride monotherapy improves glycemic control in the treatment of patients with type 2 diabetes: A 6-month randomized placebo-controlled dose-response study. The pioglitazone 001 study group. Diabetes Care 2000, 23, 1605-1611. [CrossRef] [PubMed] 
35. Levin, D.; Bell, S.; Sund, R.; Hartikainen, S.A.; Tuomilehto, J.; Pukkala, E.; Keskimaki, I.; Badrick, E.; Renehan, A.G.; Buchan, I.E.; et al. Pioglitazone and bladder cancer risk: A multipopulation pooled, cumulative exposure analysis. Diabetologia 2015, 58, 493-504. [CrossRef] [PubMed]

36. Lewis, J.D.; Habel, L.A.; Quesenberry, C.P.; Strom, B.L.; Peng, T.; Hedderson, M.M.; Ehrlich, S.F.; Mamtani, R.; Bilker, W.; Vaughn, D.J.; et al. Pioglitazone use and risk of bladder cancer and other common cancers in persons with diabetes. JAMA 2015, 314, 265-277. [CrossRef] [PubMed]

37. Derosa, G.; Maffioli, P. Dipeptidyl peptidase-4 inhibitors: 3 years of experience. Diabetes Technol. Ther. 2012, 14, 350-364. [CrossRef] [PubMed]

38. Andukuri, R.; Drincic, A.; Rendell, M. Alogliptin: A new addition to the class of dpp-4 inhibitors. Diabetes Metab. Syndr. Obes. 2009, 2, 117-126. [PubMed]

39. Kaku, K.; Katou, M.; Igeta, M.; Ohira, T.; Sano, H. Efficacy and safety of pioglitazone added to alogliptin in japanese patients with type 2 diabetes mellitus: A multicentre, randomized, double-blind, parallel-group, comparative study. Diabetes Obes. Metab. 2015, 17, 1198-1201. [CrossRef] [PubMed]

40. Kim, S.G.; Kim, D.M.; Woo, J.T.; Jang, H.C.; Chung, C.H.; Ko, K.S.; Park, J.H.; Park, Y.S.; Kim, S.J.; Choi, D.S. Efficacy and safety of lobeglitazone monotherapy in patients with type 2 diabetes mellitus over 24-weeks: A multicenter, randomized, double-blind, parallel-group, placebo controlled trial. PLoS ONE 2014, 9, e92843. [CrossRef] [PubMed]

41. Jang, J.Y.; Bae, H.; Lee, Y.J.; Choi, Y.I.; Kim, H.J.; Park, S.B.; Suh, S.W.; Kim, S.W.; Han, B.W. Structural basis for the enhanced anti-diabetic efficacy of lobeglitazone on PPARgamma. Sci. Rep. 2018, 8, 31. [CrossRef] [PubMed]

42. Mittermayer, F.; Caveney, E.; De Oliveira, C.; Gourgiotis, L.; Puri, M.; Tai, L.J.; Turner, J.R. Addressing unmet medical needs in type 2 diabetes: A narrative review of drugs under development. Curr. Diabetes Rev. 2015, 11, 17-31. [CrossRef] [PubMed]

43. Lee, H.W.; Kim, B.Y.; Ahn, J.B.; Kang, S.K.; Lee, J.H.; Shin, J.S.; Ahn, S.K.; Lee, S.J.; Yoon, S.S. Molecular design, synthesis, and hypoglycemic and hypolipidemic activities of novel pyrimidine derivatives having thiazolidinedione. Eur. J. Med. Chem. 2005, 40, 862-874. [CrossRef] [PubMed]

44. Moon, K.S.; Lee, J.E.; Lee, H.S.; Hwang, I.C.; Kim, D.H.; Park, H.K.; Choi, H.J.; Jo, W.; Son, W.C.; Yun, H.I. Ckd-501, a novel selective PPARgamma agonist, shows no carcinogenic potential in icr mice following oral administration for 104 weeks. J. Appl. Toxicol. 2014, 34, 1271-1284. [CrossRef] [PubMed]

45. Lee, H.S.; Chang, M.; Lee, J.E.; Kim, W.; Hwang, I.C.; Kim, D.H.; Park, H.K.; Choi, H.J.; Jo, W.; Cha, S.W.; et al. Carcinogenicity study of $\mathrm{ckd}-501$, a novel dual peroxisome proliferator-activated receptors alpha and gamma agonist, following oral administration to sprague dawley rats for 94-101 weeks. Regul. Toxicol. Pharmacol. 2014, 69, 207-216. [CrossRef] [PubMed]

46. Kim, S.H.; Kim, S.G.; Kim, D.M.; Woo, J.T.; Jang, H.C.; Chung, C.H.; Ko, K.S.; Park, J.H.; Park, Y.S.; Kim, S.J.; et al. Safety and efficacy of lobeglitazone monotherapy in patients with type 2 diabetes mellitus over 52 weeks: An open-label extension study. Diabetes Res. Clin. Pract. 2015, 110, e27-e30. [CrossRef] [PubMed]

47. Shin, D.; Kim, T.E.; Yoon, S.H.; Cho, J.Y.; Shin, S.G.; Jang, I.J.; Yu, K.S. Assessment of the pharmacokinetics of co-administered metformin and lobeglitazone, a thiazolidinedione antihyperglycemic agent, in healthy subjects. Curr. Med. Res. Opin. 2012, 28, 1213-1220. [CrossRef] [PubMed]

48. Choi, J.H.; Banks, A.S.; Estall, J.L.; Kajimura, S.; Bostrom, P.; Laznik, D.; Ruas, J.L.; Chalmers, M.J.; Kamenecka, T.M.; Bluher, M.; et al. Anti-diabetic drugs inhibit obesity-linked phosphorylation of PPARgamma by cdk5. Nature 2010, 466, 451-456. [CrossRef] [PubMed]

49. He, B.K.; Ning, Z.Q.; Li, Z.B.; Shan, S.; Pan, D.S.; Ko, B.C.; Li, P.P.; Shen, Z.F.; Dou, G.F.; Zhang, B.L.; et al. In vitro and in vivo characterizations of chiglitazar, a newly identified PPAR pan-agonist. PPAR Res. 2012, 2012, 546548. [CrossRef] [PubMed]

50. Konda, V.R.; Desai, A.; Darland, G.; Grayson, N.; Bland, J.S. Kdt501, a derivative from hops, normalizes glucose metabolism and body weight in rodent models of diabetes. PLoS ONE 2014, 9, e87848. [CrossRef] [PubMed]

51. Finlin, B.S.; Zhu, B.; Kok, B.P.; Godio, C.; Westgate, P.M.; Grayson, N.; Sims, R.; Bland, J.S.; Saez, E.; Kern, P.A. The influence of a kdt501, a novel isohumulone, on adipocyte function in humans. Front. Endocrinol. 2017, 8, 255. [CrossRef] [PubMed] 
52. Kern, P.A.; Finlin, B.S.; Ross, D.; Boyechko, T.; Zhu, B.; Grayson, N.; Sims, R.; Bland, J.S. Effects of kdt501 on metabolic parameters in insulin-resistant prediabetic humans. J. Endocr. Soc. 2017, 1, 650-659. [CrossRef] [PubMed]

53. Raval, P.; Jain, M.; Goswami, A.; Basu, S.; Gite, A.; Godha, A.; Pingali, H.; Raval, S.; Giri, S.; Suthar, D.; et al. Revisiting glitazars: Thiophene substituted oxazole containing alpha-ethoxy phenylpropanoic acid derivatives as highly potent PPARalpha/gamma dual agonists devoid of adverse effects in rodents. Bioorganic Med. Chem. Lett. 2011, 21, 3103-3109. [CrossRef] [PubMed]

54. Dietz, M.; Mohr, P.; Kuhn, B.; Maerki, H.P.; Hartman, P.; Ruf, A.; Benz, J.; Grether, U.; Wright, M.B. Comparative molecular profiling of the PPARalpha/gamma activator aleglitazar: PPAR selectivity, activity and interaction with cofactors. ChemMedChem 2012, 7, 1101-1111. [CrossRef] [PubMed]

55. Henry, R.R.; Lincoff, A.M.; Mudaliar, S.; Rabbia, M.; Chognot, C.; Herz, M. Effect of the dual peroxisome proliferator-activated receptor-alpha/gamma agonist aleglitazar on risk of cardiovascular disease in patients with type 2 diabetes (synchrony): A phase ii, randomised, dose-ranging study. Lancet 2009, 374, 126-135. [CrossRef]

56. Lincoff, A.M.; Tardif, J.C.; Schwartz, G.G.; Nicholls, S.J.; Ryden, L.; Neal, B.; Malmberg, K.; Wedel, H.; Buse, J.B.; Henry, R.R.; et al. Effect of aleglitazar on cardiovascular outcomes after acute coronary syndrome in patients with type 2 diabetes mellitus: The alecardio randomized clinical trial. JAMA 2014, 311, 1515-1525. [CrossRef] [PubMed]

57. Oleksiewicz, M.B.; Southgate, J.; Iversen, L.; Egerod, F.L. Rat urinary bladder carcinogenesis by dual-acting PPARalpha + gamma agonists. PPAR Res. 2008, 2008, 103167. [CrossRef] [PubMed]

58. Sasarman, A.; Letowski, J.; Czaika, G.; Ramirez, V.; Nead, M.A.; Jacobs, J.M.; Morais, R. Nucleotide sequence of the hemg gene involved in the protoporphyrinogen oxidase activity of escherichia coli k12. Can. J. Microbiol. 1993, 39, 1155-1161. [CrossRef] [PubMed]

59. Stringer, F.; Scott, G.; Valbuena, M.; Kinley, J.; Nishihara, M.; Urquhart, R. The effect of genetic polymorphisms in ugt2b15 on the pharmacokinetic profile of sipoglitazar, a novel anti-diabetic agent. Eur. J. Clin. Pharmacol. 2013, 69, 423-430. [CrossRef] [PubMed]

60. Guo, L.; Zhang, L.; Sun, Y.; Muskhelishvili, L.; Blann, E.; Dial, S.; Shi, L.; Schroth, G.; Dragan, Y.P. Differences in hepatotoxicity and gene expression profiles by anti-diabetic PPAR gamma agonists on rat primary hepatocytes and human hepg2 cells. Mol. Divers. 2006, 10, 349-360. [CrossRef] [PubMed]

61. Henriksen, K.; Byrjalsen, I.; Qvist, P.; Beck-Nielsen, H.; Hansen, G.; Riis, B.J.; Perrild, H.; Svendsen, O.L.; Gram, J.; Karsdal, M.A.; et al. Efficacy and safety of the PPARgamma partial agonist balaglitazone compared with pioglitazone and placebo: A phase iii, randomized, parallel-group study in patients with type 2 diabetes on stable insulin therapy. Diabetes Metab. Res. Rev. 2011, 27, 392-401. [CrossRef] [PubMed]

62. Minoura, H.; Takeshita, S.; Kimura, C.; Hirosumi, J.; Takakura, S.; Kawamura, I.; Seki, J.; Manda, T.; Mutoh, S. Mechanism by which a novel non-thiazolidinedione peroxisome proliferator-activated receptor gamma agonist, fk614, ameliorates insulin resistance in zucker fatty rats. Diabetes Obes. Metab. 2007, 9, 369-378. [CrossRef] [PubMed]

63. Minoura, H.; Takeshita, S.; Yamamoto, T.; Mabuchi, M.; Hirosumi, J.; Takakura, S.; Kawamura, I.; Seki, J.; Manda, T.; Ita, M.; et al. Ameliorating effect of fk614, a novel nonthiazolidinedione peroxisome proliferator-activated receptor gamma agonist, on insulin resistance in zucker fatty rat. Eur. J. Pharmacol. 2005, 519, 182-190. [CrossRef] [PubMed]

64. Minoura, H.; Takeshita, S.; Ita, M.; Hirosumi, J.; Mabuchi, M.; Kawamura, I.; Nakajima, S.; Nakayama, O.; Kayakiri, H.; Oku, T.; et al. Pharmacological characteristics of a novel nonthiazolidinedione insulin sensitizer, fk614. Eur. J. Pharmacol. 2004, 494, 273-281. [CrossRef] [PubMed]

65. Colca, J.R. Discontinued drugs in 2005: Endocrine and metabolic. Expert Opin. Investig. Drugs 2007, 16, 129-136. [CrossRef] [PubMed]

66. Colca, J.R.; Tanis, S.P.; McDonald, W.G.; Kletzien, R.F. Insulin sensitizers in 2013: New insights for the development of novel therapeutic agents to treat metabolic diseases. Expert Opin. Investig. Drugs 2014, 23, 1-7. [CrossRef] [PubMed]

67. Diani, A.R.; Peterson, T.; Sawada, G.; Jodelis, K.; Wyse, B.M.; Gilchrist, B.J.; Hearron, A.E.; Chang, A.Y. Ciglitazone, a new hypoglycemic agent. 5. Effect on renal lesions in c57bl/ksj-db/db mice. Nephron 1986, 42, 72-77. [CrossRef] [PubMed] 
68. Bortolini, M.; Wright, M.B.; Bopst, M.; Balas, B. Examining the safety of PPAR agonists—current trends and future prospects. Expert Opin. Drug Saf. 2013, 12, 65-79. [CrossRef] [PubMed]

69. Ansari, A.S.; de Lusignan, S.; Hinton, W.; Munro, N.; Taylor, S.; McGovern, A. Glycemic control is an important modifiable risk factor for uveitis in patients with diabetes: A retrospective cohort study establishing clinical risk and ophthalmic disease burden. J. Diabetes Its Complicat. 2018, 32, 602-608. [CrossRef] [PubMed]

70. Wanner, C.; Inzucchi, S.E.; Lachin, J.M.; Fitchett, D.; von Eynatten, M.; Mattheus, M.; Johansen, O.E.; Woerle, H.J.; Broedl, U.C.; Zinman, B.; et al. Empagliflozin and progression of kidney disease in type 2 diabetes. N. Engl. J. Med. 2016, 375, 323-334. [CrossRef] [PubMed]

71. Diabetes Prevention Program Research, G. Long-term effects of lifestyle intervention or metformin on diabetes development and microvascular complications over 15-year follow-up: The diabetes prevention program outcomes study. Lancet Diabetes Endocrinol. 2015, 3, 866-875.

72. Leiter, L.A.; Lundman, P.; da Silva, P.M.; Drexel, H.; Junger, C.; Gitt, A.K.; DYSIS investigators. Persistent lipid abnormalities in statin-treated patients with diabetes mellitus in europe and canada: Results of the dyslipidaemia international study. Diabet. Med. 2011, 28, 1343-1351. [CrossRef] [PubMed]

73. Feher, M.; Greener, M.; Munro, N. Persistent hypertriglyceridemia in statin-treated patients with type 2 diabetes mellitus. Diabetes Metab. Syndr. Obes. 2013, 6, 11-15. [PubMed]

74. Joshi, S.R. Saroglitazar for the treatment of dyslipidemia in diabetic patients. Expert Opin. Pharmacother. 2015, 16, 597-606. [CrossRef] [PubMed]

75. Bodkin, N.L.; Pill, J.; Meyer, K.; Hansen, B.C. The effects of k-111, a new insulin-sensitizer, on metabolic syndrome in obese prediabetic rhesus monkeys. Horm. Metab. Res. 2003, 35, 617-624. [CrossRef] [PubMed]

76. Ortmeyer, H.K.; Bodkin, N.L.; Haney, J.; Yoshioka, S.; Horikoshi, H.; Hansen, B.C. A thiazolidinedione improves in vivo insulin action on skeletal muscle glycogen synthase in insulin-resistant monkeys. Int. J. Exp. Diabetes Res. 2000, 1, 195-202. [CrossRef] [PubMed]

77. Hannah, J.S.; Bodkin, N.L.; Paidi, M.S.; Anh-Le, N.; Howard, B.V.; Hansen, B.C. Effects of acipimox on the metabolism of free fatty acids and very low lipoprotein triglyceride. Acta Diabetol. 1995, 32, 279-283. [CrossRef] [PubMed]

78. Bodkin, N.L.; Hansen, B.C. Antihypertensive effects of captopril without adverse effects on glucose tolerance in hyperinsulinemic rhesus monkeys. J. Med. Primatol. 1995, 24, 1-6. [CrossRef] [PubMed]

79. Dey, D.; Medicherla, S.; Neogi, P.; Gowri, M.; Cheng, J.; Gross, C.; Sharma, S.D.; Reaven, G.M.; Nag, B. A novel peroxisome proliferator-activated gamma (PPAR gamma) agonist, clx-0921, has potent antihyperglycemic activity with low adipogenic potential. Metabolism 2003, 52, 1012-1018. [CrossRef]

80. Medicherla, S.; Dey, D.; Neogi, P.; Lakner, F.J.; Nag, B. Clx-0921: A new PPAR-gamma agonist anti-diabetic thiazolidinedione compound. Diabetes 2000, 49, A117.

81. Soleymanian, T.; Hamid, G.; Arefi, M.; Najafi, I.; Ganji, M.R.; Amini, M.; Hakemi, M.; Tehrani, M.R.; Larijani, B. Non-diabetic renal disease with or without diabetic nephropathy in type 2 diabetes: Clinical predictors and outcome. Ren. Fail. 2015, 37, 572-575. [CrossRef] [PubMed]

82. Centers for Disease Control and Prevention. Incidence of end-stage renal disease attributed to diabetes among persons with diagnosed diabetes—united states and puerto rico, 1996-2007. MMWR 2010, 59, 1361-1366.

83. Weil, E.J.; Lemley, K.V.; Mason, C.C.; Yee, B.; Jones, L.I.; Blouch, K.; Lovato, T.; Richardson, M.; Myers, B.D.; Nelson, R.G. Podocyte detachment and reduced glomerular capillary endothelial fenestration promote kidney disease in type 2 diabetic nephropathy. Kidney Int. 2012, 82, 1010-1017. [CrossRef] [PubMed]

84. Henique, C.; Bollee, G.; Lenoir, O.; Dhaun, N.; Camus, M.; Chipont, A.; Flosseau, K.; Mandet, C.; Yamamoto, M.; Karras, A.; et al. Nuclear factor erythroid 2-related factor 2 drives podocyte-specific expression of peroxisome proliferator-activated receptor gamma essential for resistance to crescentic gn. JASN 2016, 27, 172-188. [CrossRef] [PubMed]

85. Zhang, J.; Villacorta, L.; Chang, L.; Fan, Z.; Hamblin, M.; Zhu, T.; Chen, C.S.; Cole, M.P.; Schopfer, F.J.; Deng, C.X.; et al. Nitro-oleic acid inhibits angiotensin ii-induced hypertension. Circ. Res. 2010, 107, 540-548. [CrossRef] [PubMed]

86. Cole, M.P.; Rudolph, T.K.; Khoo, N.K.; Motanya, U.N.; Golin-Bisello, F.; Wertz, J.W.; Schopfer, F.J.; Rudolph, V.; Woodcock, S.R.; Bolisetty, S.; et al. Nitro-fatty acid inhibition of neointima formation after endoluminal vessel injury. Circ. Res. 2009, 105, 965-972. [CrossRef] [PubMed] 
87. Wang, H.; Liu, H.; Jia, Z.; Guan, G.; Yang, T. Effects of endogenous PPAR agonist nitro-oleic acid on metabolic syndrome in obese zucker rats. PPAR Res. 2010, 2010, 601562. [CrossRef] [PubMed]

88. Schopfer, F.J.; Cole, M.P.; Groeger, A.L.; Chen, C.S.; Khoo, N.K.; Woodcock, S.R.; Golin-Bisello, F.; Motanya, U.N.; Li, Y.; Zhang, J.; et al. Covalent peroxisome proliferator-activated receptor gamma adduction by nitro-fatty acids: Selective ligand activity and anti-diabetic signaling actions. J. Biol. Chem. 2010, 285, 12321-12333. [CrossRef] [PubMed]

89. Nie, H.; Xue, X.; Li, J.; Liu, X.; Lv, S.; Guan, G.; Liu, H.; Liu, G.; Liu, S.; Chen, Z. Nitro-oleic acid attenuates ogd/r-triggered apoptosis in renal tubular cells via inhibition of bax mitochondrial translocation in a PPAR-gamma-dependent manner. Cell. Physiol. Biochem. 2015, 35, 1201-1218. [CrossRef] [PubMed]

90. Taygerly, J.P.; McGee, L.R.; Rubenstein, S.M.; Houze, J.B.; Cushing, T.D.; Li, Y.; Motani, A.; Chen, J.L.; Frankmoelle, W.; Ye, G.; et al. Discovery of int131: A selective PPARgamma modulator that enhances insulin sensitivity. Bioorganic Med. Chem. 2013, 21, 979-992. [CrossRef] [PubMed]

91. Kintscher, U.; Goebel, M. Int-131, a PPARgamma agonist for the treatment of type 2 diabetes. Curr. Opin. Investig. Drugs 2009, 10, 381-387. [PubMed]

92. Berge, R.K.; Tronstad, K.J.; Berge, K.; Rost, T.H.; Wergedahl, H.; Gudbrandsen, O.A.; Skorve, J. The metabolic syndrome and the hepatic fatty acid drainage hypothesis. Biochimie 2005, 87, 15-20. [CrossRef] [PubMed]

93. Berge, R.K.; Hvattum, E. Impact of cytochrome p450 system on lipoprotein metabolism. Effect of abnormal fatty acids (3-thia fatty acids). Pharmacol. Ther. 1994, 61, 345-383. [CrossRef]

94. Vaagenes, H.; Madsen, L.; Asiedu, D.K.; Lillehaug, J.R.; Berge, R.K. Early modulation of genes encoding peroxisomal and mitochondrial beta-oxidation enzymes by 3-thia fatty acids. Biochem. Pharmacol. 1998, 56, 1571-1582. [CrossRef]

95. Wensaas, A.J.; Rustan, A.C.; Just, M.; Berge, R.K.; Drevon, C.A.; Gaster, M. Fatty acid incubation of myotubes from humans with type 2 diabetes leads to enhanced release of beta-oxidation products because of impaired fatty acid oxidation: Effects of tetradecylthioacetic acid and eicosapentaenoic acid. Diabetes 2009, 58, 527-535. [CrossRef] [PubMed]

96. Hafstad, A.D.; Khalid, A.M.; Hagve, M.; Lund, T.; Larsen, T.S.; Severson, D.L.; Clarke, K.; Berge, R.K.; Aasum, E. Cardiac peroxisome proliferator-activated receptor-alpha activation causes increased fatty acid oxidation, reducing efficiency and post-ischaemic functional loss. Cardiovasc. Res. 2009, 83, 519-526. [CrossRef] [PubMed]

97. Laurent, D.; Gounarides, J.S.; Gao, J.; Boettcher, B.R. Effects of cevoglitazar, a dual PPARalpha/gamma agonist, on ectopic fat deposition in fatty zucker rats. Diabetes Obes. Metabol. 2009, 11, 632-636.

98. Chen, H.; Dardik, B.; Qiu, L.; Ren, X.; Caplan, S.L.; Burkey, B.; Boettcher, B.R.; Gromada, J. Cevoglitazar, a novel peroxisome proliferator-activated receptor-alpha/gamma dual agonist, potently reduces food intake and body weight in obese mice and cynomolgus monkeys. Endocrinology 2010, 151, 3115-3124. [CrossRef] [PubMed]

99. Colca, J.R. Discontinued drugs in 2008: Endocrine and metabolic. Expert Opin. Investig. Drugs 2009, 18, 1243-1255. [CrossRef] [PubMed]

100. Murakami, K.; Tobe, K.; Ide, T.; Mochizuki, T.; Ohashi, M.; Akanuma, Y.; Yazaki, Y.; Kadowaki, T. A novel insulin sensitizer acts as a coligand for peroxisome proliferator-activated receptor-alpha (PPAR-alpha) and PPAR-gamma: Effect of ppar-alpha activation on abnormal lipid metabolism in liver of zucker fatty rats. Diabetes 1998, 47, 1841-1847. [CrossRef] [PubMed]

101. Nomura, M.; Kinoshita, S.; Satoh, H.; Maeda, T.; Murakami, K.; Tsunoda, M.; Miyachi, H.; Awano, K. (3-substituted benzyl)thiazolidine-2,4-diones as structurally new antihyperglycemic agents. Bioorganic Med. Chem. Lett. 1999, 9, 533-538. [CrossRef]

102. Doebber, T.W.; Kelly, L.J.; Zhou, G.; Meurer, R.; Biswas, C.; Li, Y.; Wu, M.S.; Ippolito, M.C.; Chao, Y.S.; Wang, P.R.; et al. Mk-0767, a novel dual PPARalpha/gamma agonist, displays robust antihyperglycemic and hypolipidemic activities. Biochem. Biophys. Res. Commun. 2004, 318, 323-328. [CrossRef] [PubMed]

103. Oleksiewicz, M.B.; Thorup, I.; Nielsen, H.S.; Andersen, H.V.; Hegelund, A.C.; Iversen, L.; Guldberg, T.S.; Brinck, P.R.; Sjogren, I.; Thinggaard, U.K.; et al. Generalized cellular hypertrophy is induced by a dual-acting PPAR agonist in rat urinary bladder urothelium in vivo. Toxicol. Pathol. 2005, 33, 552-560. [CrossRef] [PubMed] 
104. Evans, J.L.; Lin, J.J.; Goldfine, I.D. Novel approach to treat insulin resistance, type 2 diabetes, and the metabolic syndrome: Simultaneous activation of PPARalpha, PPARgamma, and PPARdelta. Curr. Diabetes Rev. 2005, 1, 299-307. [CrossRef] [PubMed]

105. Cheang, W.S.; Tian, X.Y.; Wong, W.T.; Huang, Y. The peroxisome proliferator-activated receptors in cardiovascular diseases: Experimental benefits and clinical challenges. Br. J. Pharmacol. 2015, 172, 5512-5522. [CrossRef] [PubMed]

106. Goto, T.; Nakayama, R.; Yamanaka, M.; Takata, M.; Takazawa, T.; Watanabe, K.; Maruta, K.; Nagata, R.; Nagamine, J.; Tsuchida, A.; et al. Effects of dsp-8658, a novel selective peroxisome proliferator-activated receptors a/gamma modulator, on adipogenesis and glucose metabolism in diabetic obese mice. Exp. Clin. Endocrinol. Diabetes 2015, 123, 492-499. [PubMed]

107. Bray, G.A.; Fruhbeck, G.; Ryan, D.H.; Wilding, J.P. Management of obesity. Lancet 2016, 387, $1947-1956$. [CrossRef]

108. Xu, P.; Dai, S.; Wang, J.; Zhang, J.; Liu, J.; Wang, F.; Zhai, Y. Preventive obesity agent montmorillonite adsorbs dietary lipids and enhances lipid excretion from the digestive tract. Sci. Rep. 2016, 6, 19659. [CrossRef] [PubMed]

109. Xu, P.; Wang, J.; Hong, F.; Wang, S.; Jin, X.; Xue, T.; Jia, L.; Zhai, Y. Melatonin prevents obesity through modulation of gut microbiota in mice. J. Pineal Res. 2017, 62. [CrossRef] [PubMed]

110. Vazquez-Carrera, M. Unraveling the effects of PPARbeta/delta on insulin resistance and cardiovascular disease. Trends Endocrinol. Metab. 2016, 27, 319-334. [CrossRef] [PubMed]

111. Vassilatou, E. Nonalcoholic fatty liver disease and polycystic ovary syndrome. World J. Gastroenterol. 2014, 20, 8351-8363. [CrossRef] [PubMed]

112. Xu, P.; Hong, F.; Wang, J.; Cong, Y.; Dai, S.; Wang, S.; Wang, J.; Jin, X.; Wang, F.; Liu, J.; et al. Microbiome remodeling via the montmorillonite adsorption-excretion axis prevents obesity-related metabolic disorders. EBioMedicine 2017, 16, 251-261. [CrossRef] [PubMed]

113. Lovren, F.; Teoh, H.; Verma, S. Obesity and atherosclerosis: Mechanistic insights. Can. J. Cardiol. 2015, 31, 177-183. [CrossRef] [PubMed]

114. Oda, N.; Imamura, S.; Fujita, T.; Uchida, Y.; Inagaki, K.; Kakizawa, H.; Hayakawa, N.; Suzuki, A.; Takeda, J.; Horikawa, Y.; et al. The ratio of leptin to adiponectin can be used as an index of insulin resistance. Metabolism 2008, 57, 268-273. [CrossRef] [PubMed]

115. Lalloyer, F.; Staels, B. Fibrates, glitazones, and peroxisome proliferator-activated receptors. Arterioscler. Thromb. Vasc. Biol. 2010, 30, 894-899. [CrossRef] [PubMed]

116. Robins, S.J.; Collins, D.; Wittes, J.T.; Papademetriou, V.; Deedwania, P.C.; Schaefer, E.J.; McNamara, J.R.; Kashyap, M.L.; Hershman, J.M.; Wexler, L.F.; et al. Relation of gemfibrozil treatment and lipid levels with major coronary events: Va-hit: A randomized controlled trial. JAMA 2001, 285, 1585-1591. [CrossRef] [PubMed]

117. Rodriguez-Cuenca, S.; Carobbio, S.; Barcelo-Coblijn, G.; Prieur, X.; Relat, J.; Amat, R.; Campbell, M.; Dias, A.R.; Bahri, M.; Gray, S.L.; et al. P465l PPARgamma mutation confers partial resistance to the hypolipidemic action of fibrates. Diabetes Obes. Metab. 2018. [CrossRef] [PubMed]

118. Seiler, C.; Suter, T.M.; Hess, O.M. Exercise-induced vasomotion of angiographically normal and stenotic coronary arteries improves after cholesterol-lowering drug therapy with bezafibrate. J. Am. Coll. Cardiol. 1995, 26, 1615-1622. [CrossRef]

119. Khera, A.V.; Qamar, A.; Reilly, M.P.; Dunbar, R.L.; Rader, D.J. Effects of niacin, statin, and fenofibrate on circulating proprotein convertase subtilisin/kexin type 9 levels in patients with dyslipidemia. Am. J. Cardiol. 2015, 115, 178-182. [CrossRef] [PubMed]

120. Evans, M.; Anderson, R.A.; Graham, J.; Ellis, G.R.; Morris, K.; Davies, S.; Jackson, S.K.; Lewis, M.J.; Frenneaux, M.P.; Rees, A. Ciprofibrate therapy improves endothelial function and reduces postprandial lipemia and oxidative stress in type 2 diabetes mellitus. Circulation 2000, 101, 1773-1779. [CrossRef] [PubMed]

121. Song, D.; Chu, Z.; Min, L.; Zhen, T.; Li, P.; Han, L.; Bu, S.; Yang, J.; Gonzale, F.J.; Liu, A. Gemfibrozil not fenofibrate decreases systemic glucose level via PPARalpha. Die Pharm. 2016, 71, 205-212.

122. Parhofer, K.G. The treatment of disorders of lipid metabolism. Deutsch. Arzteblatt Int. 2016, 113, $261-268$. [CrossRef] [PubMed] 
123. Committee of Principal Investigators. WHO Cooperative trial on primary prevention of ischaemic heart disease using clofibrate to lower serum cholesterol: Mortality follow-up. Report of the committee of principal investigators. Lancet 1980, 2, 379-385.

124. Fazio, S.; Linton, M.F. The role of fibrates in managing hyperlipidemia: Mechanisms of action and clinical efficacy. Curr. Atheroscler. Rep. 2004, 6, 148-157. [CrossRef] [PubMed]

125. Keating, G.M.; Croom, K.F. Fenofibrate: A review of its use in primary dyslipidaemia, the metabolic syndrome and type 2 diabetes mellitus. Drugs 2007, 67, 121-153. [CrossRef] [PubMed]

126. Moutzouri, E.; Kei, A.; Elisaf, M.S.; Milionis, H.J. Management of dyslipidemias with fibrates, alone and in combination with statins: Role of delayed-release fenofibric acid. Vasc. Health Risk Manag. 2010, 6, 525-539. [PubMed]

127. Chachad, S.S.; Gole, M.; Malhotra, G.; Naidu, R. Comparison of pharmacokinetics of two fenofibrate tablet formulations in healthy human subjects. Clin. Ther. 2014, 36, 967-973. [CrossRef] [PubMed]

128. Zhang, X.; Chen, G.; Zhang, T.; Ma, Z.; Wu, B. Effects of pegylated lipid nanoparticles on the oral absorption of one bcs ii drug: A mechanistic investigation. Int. J. Nanomed. 2014, 9, 5503-5514.

129. Brown, W.V. Treatment of hypercholesterolaemia with fenofibrate: A review. Curr. Med. Res. Opin. 1989, 11, 321-330. [CrossRef] [PubMed]

130. Pellegrini, M.; Pallottini, V.; Marin, R.; Marino, M. Role of the sex hormone estrogen in the prevention of lipid disorder. Curr. Med. Chem. 2014, 21, 2734-2742. [CrossRef] [PubMed]

131. Tenenbaum, A.; Motro, M.; Fisman, E.Z. Dual and pan-peroxisome proliferator-activated receptors (PPAR) co-agonism: The bezafibrate lessons. Cardiovasc. Diabetol. 2005, 4, 14. [CrossRef] [PubMed]

132. Ericsson, C.G.; Hamsten, A.; Nilsson, J.; Grip, L.; Svane, B.; de Faire, U. Angiographic assessment of effects of bezafibrate on progression of coronary artery disease in young male postinfarction patients. Lancet 1996, 347, 849-853. [CrossRef]

133. Staels, B.; Dallongeville, J.; Auwerx, J.; Schoonjans, K.; Leitersdorf, E.; Fruchart, J.C. Mechanism of action of fibrates on lipid and lipoprotein metabolism. Circulation 1998, 98, 2088-2093. [CrossRef] [PubMed]

134. Saku, K.; Gartside, P.S.; Hynd, B.A.; Kashyap, M.L. Mechanism of action of gemfibrozil on lipoprotein metabolism. J. Clin. Investig. 1985, 75, 1702-1712. [CrossRef] [PubMed]

135. Mikhailidis, D.P.; Jagroon, I.A. Ciprofibrate versus gemfibrozil in the treatment of mixed hyperlipidemias: An open-label, multicenter study. Metabolism 2001, 50, 1385-1386. [CrossRef]

136. Rizos, E.; Bairaktari, E.; Ganotakis, E.; Tsimihodimos, V.; Mikhailidis, D.P.; Elisaf, M. Effect of ciprofibrate on lipoproteins, fibrinogen, renal function, and hepatic enzymes. J. Cardiovasc. Pharmacol. Ther. 2002, 7, 219-226. [CrossRef] [PubMed]

137. Fruchart, J.C. Selective peroxisome proliferator-activated receptor alpha modulators (sPPARmalpha): The next generation of peroxisome proliferator-activated receptor alpha-agonists. Cardiovasc. Diabetol. 2013, 12, 82. [CrossRef] [PubMed]

138. Yamazaki, Y.; Abe, K.; Toma, T.; Nishikawa, M.; Ozawa, H.; Okuda, A.; Araki, T.; Oda, S.; Inoue, K.; Shibuya, K.; et al. Design and synthesis of highly potent and selective human peroxisome proliferator-activated receptor alpha agonists. Bioorganic Med. Chem. Lett. 2007, 17, 4689-4693. [CrossRef] [PubMed]

139. Hennuyer, N.; Duplan, I.; Paquet, C.; Vanhoutte, J.; Woitrain, E.; Touche, V.; Colin, S.; Vallez, E.; Lestavel, S.; Lefebvre, P.; et al. The novel selective PPARalpha modulator (sPPARmalpha) pemafibrate improves dyslipidemia, enhances reverse cholesterol transport and decreases inflammation and atherosclerosis. Atherosclerosis 2016, 249, 200-208. [CrossRef] [PubMed]

140. Schima, S.M.; Maciejewski, S.R.; Hilleman, D.E.; Williams, M.A.; Mohiuddin, S.M. Fibrate therapy in the management of dyslipidemias, alone and in combination with statins: Role of delayed-release fenofibric acid. Expert Opin. Pharmacother. 2010, 11, 731-738. [CrossRef] [PubMed]

141. Athyros, V.G.; Mikhailidis, D.P.; Papageorgiou, A.A.; Didangelos, T.P.; Peletidou, A.; Kleta, D.; Karagiannis, A.; Kakafika, A.I.; Tziomalos, K.; Elisaf, M. Targeting vascular risk in patients with metabolic syndrome but without diabetes. Metabolism 2005, 54, 1065-1074. [CrossRef] [PubMed]

142. Mohiuddin, S.M.; Pepine, C.J.; Kelly, M.T.; Buttler, S.M.; Setze, C.M.; Sleep, D.J.; Stolzenbach, J.C. Efficacy and safety of abt-335 (fenofibric acid) in combination with simvastatin in patients with mixed dyslipidemia: A phase 3, randomized, controlled study. Am. Heart J. 2009, 157, 195-203. [CrossRef] [PubMed] 
143. Shek, A.; Ferrill, M.J. Statin-fibrate combination therapy. Ann. Pharmacother. 2001, 35, 908-917. [CrossRef] [PubMed]

144. Backes, J.M.; Gibson, C.A.; Ruisinger, J.F.; Moriarty, P.M. Fibrates: What have we learned in the past 40 years? Pharmacotherapy 2007, 27, 412-424. [CrossRef] [PubMed]

145. Chalasani, N.; Younossi, Z.; Lavine, J.E.; Diehl, A.M.; Brunt, E.M.; Cusi, K.; Charlton, M.; Sanyal, A.J. The diagnosis and management of non-alcoholic fatty liver disease: Practice guideline by the american association for the study of liver diseases, american college of gastroenterology, and the american gastroenterological association. Hepatology 2012, 55, 2005-2023. [CrossRef] [PubMed]

146. Ratziu, V.; Bellentani, S.; Cortez-Pinto, H.; Day, C.; Marchesini, G. A position statement on nafld/nash based on the easl 2009 special conference. J. Hepatol. 2010, 53, 372-384. [CrossRef] [PubMed]

147. Staels, B.; Rubenstrunk, A.; Noel, B.; Rigou, G.; Delataille, P.; Millatt, L.J.; Baron, M.; Lucas, A.; Tailleux, A.; Hum, D.W.; et al. Hepatoprotective effects of the dual peroxisome proliferator-activated receptor alpha/delta agonist, gft505, in rodent models of nonalcoholic fatty liver disease/nonalcoholic steatohepatitis. Hepatology 2013, 58, 1941-1952. [CrossRef] [PubMed]

148. Cariou, B.; Hanf, R.; Lambert-Porcheron, S.; Zair, Y.; Sauvinet, V.; Noel, B.; Flet, L.; Vidal, H.; Staels, B.; Laville, M. Dual peroxisome proliferator-activated receptor alpha/delta agonist gft505 improves hepatic and peripheral insulin sensitivity in abdominally obese subjects. Diabetes Care 2013, 36, 2923-2930. [CrossRef] [PubMed]

149. Cariou, B.; Zair, Y.; Staels, B.; Bruckert, E. Effects of the new dual PPAR alpha/delta agonist gft505 on lipid and glucose homeostasis in abdominally obese patients with combined dyslipidemia or impaired glucose metabolism. Diabetes Care 2011, 34, 2008-2014. [CrossRef] [PubMed]

150. Bays, H.E.; Hallen, J.; Vige, R.; Fraser, D.; Zhou, R.; Hustvedt, S.O.; Orloff, D.G.; Kastelein, J.J. Icosabutate for the treatment of very high triglycerides: A placebo-controlled, randomized, double-blind, 12-week clinical trial. J. Clin. Lipidol. 2016, 10, 181-191. [CrossRef] [PubMed]

151. Fraser, D.A.; Skjaeret, T.; Qin, Y.; Larsen, L.N.; Husberg, C.; Hovland, R.; Pieterman, E.J.; van den Hoek, A.M.; Princen, H.M.; Hustvedt, S.O. Icosabutate, a novel structurally enhanced fatty-acid increases hepatic uptake of cholesterol and triglycerides in conjunction with increased hepatic LDL receptor expression. Circulation 2014, 130, A11889.

152. Billin, A.N. PPAR-beta/delta agonists for type 2 diabetes and dyslipidemia: An adopted orphan still looking for a home. Expert Opin. Investig. Drugs 2008, 17, 1465-1471. [CrossRef] [PubMed]

153. Strain, J.D.; Farver, D.K.; Clem, J.R. A review on the rationale and clinical use of concomitant rosuvastatin and fenofibrate/fenofibric acid therapy. Clin. Pharmacol. 2010, 2, 95-104. [CrossRef] [PubMed]

154. Harchaoui, K.E.; Visser, M.E.; Kastelein, J.J.; Stroes, E.S.; Dallinga-Thie, G.M. Triglycerides and cardiovascular risk. Curr. Cardiol. Rev. 2009, 5, 216-222. [CrossRef] [PubMed]

155. Stone, N.J.; Robinson, J.G.; Lichtenstein, A.H.; Bairey Merz, C.N.; Blum, C.B.; Eckel, R.H.; Goldberg, A.C.; Gordon, D.; Levy, D.; Lloyd-Jones, D.M.; et al. 2013 acc/aha guideline on the treatment of blood cholesterol to reduce atherosclerotic cardiovascular risk in adults: A report of the american college of cardiology/american heart association task force on practice guidelines. J. Am. Coll. Cardiol. 2014, 63, 2889-2934. [CrossRef] [PubMed]

156. Baigent, C.; Keech, A.; Kearney, P.M.; Blackwell, L.; Buck, G.; Pollicino, C.; Kirby, A.; Sourjina, T.; Peto, R.; Collins, R.; et al. Efficacy and safety of cholesterol-lowering treatment: Prospective meta-analysis of data from 90,056 participants in 14 randomised trials of statins. Lancet 2005, 366, 1267-1278. [PubMed]

157. Chapman, M.J.; Redfern, J.S.; McGovern, M.E.; Giral, P. Niacin and fibrates in atherogenic dyslipidemia: Pharmacotherapy to reduce cardiovascular risk. Pharmacol. Ther. 2010, 126, 314-345. [CrossRef] [PubMed]

158. Shitara, Y.; Sugiyama, Y. Pharmacokinetic and pharmacodynamic alterations of 3-hydroxy-3-methylglutaryl coenzyme a (hmg-coa) reductase inhibitors: Drug-drug interactions and interindividual differences in transporter and metabolic enzyme functions. Pharmacol. Ther. 2006, 112, 71-105. [CrossRef] [PubMed]

159. Aoki, T.; Nishimura, H.; Nakagawa, S.; Kojima, J.; Suzuki, H.; Tamaki, T.; Wada, Y.; Yokoo, N.; Sato, F.; Kimata, H.; et al. Pharmacological profile of a novel synthetic inhibitor of 3-hydroxy-3-methylglutaryl-coenzyme a reductase. Arzneimittel-Forschung 1997, 47, 904-909. [PubMed]

160. Wakida, Y.; Suzuki, S.; Nomura, H.; Isomura, T. Additional treatment with fenofibrate for patients treated with pitavastatin under ordinary medical practice for hypertriglyceridemia in japan (approach-j study). Jpn. Clin. Med. 2011, 2, 57-66. [CrossRef] [PubMed] 
161. Tokuno, A.; Hirano, T.; Hayashi, T.; Mori, Y.; Yamamoto, T.; Nagashima, M.; Shiraishi, Y.; Ito, Y.; Adachi, M. The effects of statin and fibrate on lowering small dense LDL- cholesterol in hyperlipidemic patients with type 2 diabetes. J. Atheroscler. Thromb. 2007, 14, 128-132. [CrossRef] [PubMed]

162. Bisgaier, C.L.; Oniciu, D.C.; Srivastava, R.A.K. Comparative evaluation of gemcabene and PPAR ligands in transcriptional assays of peroxisome proliferator-activated receptors: Implication for the treatment of hyperlipidemia and cardiovascular disease. J. Cardiovasc. Pharmacol. 2018, 72, 3-10. [CrossRef] [PubMed]

163. Ridker, P.M.; MacFadyen, J.G.; Thuren, T.; Everett, B.M.; Libby, P.; Glynn, R.J.; Group, C.T. Effect of interleukin-1beta inhibition with canakinumab on incident lung cancer in patients with atherosclerosis: Exploratory results from a randomised, double-blind, placebo-controlled trial. Lancet 2017, 390, 1833-1842. [CrossRef]

164. Srivastava, R.A.K.; Cornicelli, J.A.; Markham, B.; Bisgaier, C.L. Gemcabene, a first-in-class lipid-lowering agent in late-stage development, down-regulates acute-phase c-reactive protein via c/ebp-delta-mediated transcriptional mechanism. Mol. Cell. Biochem. 2018. [CrossRef] [PubMed]

165. Zhao, H.P.; Zhang, X.S.; Xiang, B.R. Discontinued drugs in 2010: Cardiovascular drugs. Expert Opin. Investig. Drugs 2011, 20, 1311-1325. [CrossRef] [PubMed]

166. Sprecher, D.L. Lipids, lipoproteins, and peroxisome proliferator activated receptor-delta. Am. J. Cardiol. 2007, 100, S20-S24. [CrossRef] [PubMed]

167. Sprecher, D.L.; Massien, C.; Pearce, G.; Billin, A.N.; Perlstein, I.; Willson, T.M.; Hassall, D.G.; Ancellin, N.; Patterson, S.D.; Lobe, D.C.; et al. Triglyceride:High-density lipoprotein cholesterol effects in healthy subjects administered a peroxisome proliferator activated receptor delta agonist. Arterioscler. Thromb. Vasc. Biol. 2007, 27, 359-365. [CrossRef] [PubMed]

168. Reilly, S.M.; Lee, C.H. PPAR delta as a therapeutic target in metabolic disease. FEBS Lett. 2008, 582, $26-31$. [CrossRef] [PubMed]

169. Madrazo, J.A.; Kelly, D.P. The PPAR trio: Regulators of myocardial energy metabolism in health and disease. J. Mol. Cell. Cardiol. 2008, 44, 968-975. [CrossRef] [PubMed]

170. Schmuth, M.; Jiang, Y.J.; Dubrac, S.; Elias, P.M.; Feingold, K.R. Thematic review series: Skin lipids. Peroxisome proliferator-activated receptors and liver $x$ receptors in epidermal biology. J. Lipid Res. 2008, 49, 499-509. [CrossRef] [PubMed]

171. Iwashita, A.; Muramatsu, Y.; Yamazaki, T.; Muramoto, M.; Kita, Y.; Yamazaki, S.; Mihara, K.; Moriguchi, A.; Matsuoka, N. Neuroprotective efficacy of the peroxisome proliferator-activated receptor delta-selective agonists in vitro and in vivo. J. Pharmacol. Exp. Ther. 2007, 320, 1087-1096. [CrossRef] [PubMed]

172. Peters, J.M.; Hollingshead, H.E.; Gonzalez, F.J. Role of peroxisome-proliferator-activated receptor beta/delta (PPARbeta/delta) in gastrointestinal tract function and disease. Clin. Sci. 2008, 115, 107-127. [CrossRef] [PubMed]

173. Hirschfield, G.M.; Gershwin, M.E. The immunobiology and pathophysiology of primary biliary cirrhosis. Ann. Rev. Pathol. 2013, 8, 303-330. [CrossRef] [PubMed]

174. Nevens, F.; Andreone, P.; Mazzella, G.; Strasser, S.I.; Bowlus, C.; Invernizzi, P.; Drenth, J.P.; Pockros, P.J.; Regula, J.; Beuers, U.; et al. A placebo-controlled trial of obeticholic acid in primary biliary cholangitis. $N$. Engl. J. Med. 2016, 375, 631-643. [CrossRef] [PubMed]

175. Corpechot, C.; Abenavoli, L.; Rabahi, N.; Chretien, Y.; Andreani, T.; Johanet, C.; Chazouilleres, O.; Poupon, R. Biochemical response to ursodeoxycholic acid and long-term prognosis in primary biliary cirrhosis. Hepatology 2008, 48, 871-877. [CrossRef] [PubMed]

176. Bays, H.E.; Schwartz, S.; Littlejohn, T., 3rd; Kerzner, B.; Krauss, R.M.; Karpf, D.B.; Choi, Y.J.; Wang, X.; Naim, S.; Roberts, B.K. Mbx-8025, a novel peroxisome proliferator receptor-delta agonist: Lipid and other metabolic effects in dyslipidemic overweight patients treated with and without atorvastatin. J. Clin. Endocrinol. Metab. 2011, 96, 2889-2897. [CrossRef] [PubMed]

177. Haczeyni, F.; Wang, H.; Barn, V.; Mridha, A.R.; Yeh, M.M.; Haigh, W.G.; Ioannou, G.N.; Choi, Y.J.; McWherter, C.A.; Teoh, N.C.; et al. The selective peroxisome proliferator-activated receptor-delta agonist seladelpar reverses nonalcoholic steatohepatitis pathology by abrogating lipotoxicity in diabetic obese mice. Hepatol. Commun. 2017, 1, 663-674. [CrossRef] [PubMed]

178. Jones, D.; Boudes, P.F.; Swain, M.G.; Bowlus, C.L.; Galambos, M.R.; Bacon, B.R.; Doerffel, Y.; Gitlin, N.; Gordon, S.C.; Odin, J.A.; et al. Seladelpar (mbx-8025), a selective PPAR-delta agonist, in patients with primary biliary cholangitis with an inadequate response to ursodeoxycholic acid: A double-blind, randomised, 
placebo-controlled, phase 2, proof-of-concept study. Lancet. Gastroenterol. Hepatol. 2017, 2, 716-726. [CrossRef]

179. Wertheimer, A.; Morlock, R.; Becker, M.A. A revised estimate of the burden of illness of gout. Curr. Ther. Res. Clin. Exp. 2013, 75, 1-4. [CrossRef] [PubMed]

180. Edwards, N.L.; Sundy, J.S.; Forsythe, A.; Blume, S.; Pan, F.; Becker, M.A. Work productivity loss due to flares in patients with chronic gout refractory to conventional therapy. J. Med. Econ. 2011, 14, 10-15. [CrossRef] [PubMed]

181. Brook, R.A.; Forsythe, A.; Smeeding, J.E.; Lawrence Edwards, N. Chronic gout: Epidemiology, disease progression, treatment and disease burden. Curr. Med. Res. Opin. 2010, 26, 2813-2821. [CrossRef] [PubMed]

182. Aronow, W.S.; Harding, P.R.; Khursheed, M.; Vangrow, J.S.; Papageorge's, N.P. Effect of halofenate on serum uric acid. Clin. Pharmacol. Ther. 1973, 14, 371-373. [CrossRef] [PubMed]

183. Aronow, W.S.; Harding, P.R.; Khursheed, M.; Vangrow, J.S.; Papageorge's, N.P.; Mays, J. Effect of halofenate on serum lipids. Clin. Pharmacol. Ther. 1973, 14, 358-365. [CrossRef] [PubMed]

184. Poiley, J.; Steinberg, A.S.; Choi, Y.J.; Davis, C.S.; Martin, R.L.; McWherter, C.A.; Boudes, P.F.; Arhalofenate Flare Study, I. A randomized, double-blind, active- and placebo-controlled efficacy and safety study of arhalofenate for reducing flare in patients with gout. Arthritis Rheumatol. 2016, 68, 2027-2034. [CrossRef] [PubMed]

185. Tong, M.; Deochand, C.; Didsbury, J.; de la Monte, S.M. T3d-959: A multi-faceted disease remedial drug candidate for the treatment of alzheimer's disease. J. Alzheimer's Dis. 2016, 51, 123-138. [CrossRef] [PubMed]

186. Tong, M.; Dominguez, C.; Didsbury, J.; de la Monte, S.M. Targeting alzheimer's disease neuro-metabolic dysfunction with a small molecule nuclear receptor agonist (t3d-959) reverses disease pathologies. J. Alzheimer's Dis. Parkinsonism 2016, 6, pii:238. [CrossRef] [PubMed]

187. Jemal, A.; Bray, F.; Center, M.M.; Ferlay, J.; Ward, E.; Forman, D. Global cancer statistics. CA Cancer J. Clin. 2011, 61, 69-90. [CrossRef] [PubMed]

188. Koyi, H.; Hillerdal, G.; Branden, E. A prospective study of a total material of lung cancer from a county in sweden 1997-1999: Gender, symptoms, type, stage, and smoking habits. Lung Cancer 2002, 36, 9-14. [CrossRef]

189. Schiller, J.H.; Harrington, D.; Belani, C.P.; Langer, C.; Sandler, A.; Krook, J.; Zhu, J.; Johnson, D.H.; Eastern Cooperative Oncology, G. Comparison of four chemotherapy regimens for advanced non-small-cell lung cancer. N. Engl. J. Med. 2002, 346, 92-98. [CrossRef] [PubMed]

190. Blanquicett, C.; Roman, J.; Hart, C.M. Thiazolidinediones as anti-cancer agents. Cancer Ther. 2008, 6, $25-34$. [PubMed]

191. Nemenoff, R.A.; Weiser-Evans, M.; Winn, R.A. Activation and molecular targets of peroxisome proliferator-activated receptor-gamma ligands in lung cancer. PPAR Res. 2008, 2008, 156875. [CrossRef] [PubMed]

192. Pishvaian, M.J.; Marshall, J.L.; Wagner, A.J.; Hwang, J.J.; Malik, S.; Cotarla, I.; Deeken, J.F.; He, A.R.; Daniel, H.; Halim, A.B.; et al. A phase 1 study of efatutazone, an oral peroxisome proliferator-activated receptor gamma agonist, administered to patients with advanced malignancies. Cancer 2012, 118, 5403-5413. [CrossRef] [PubMed]

193. Copland, J.A.; Marlow, L.A.; Kurakata, S.; Fujiwara, K.; Wong, A.K.; Kreinest, P.A.; Williams, S.F.; Haugen, B.R.; Klopper, J.P.; Smallridge, R.C. Novel high-affinity PPARgamma agonist alone and in combination with paclitaxel inhibits human anaplastic thyroid carcinoma tumor growth via p21waf1/cip1. Oncogene 2006, 25, 2304-2317. [CrossRef] [PubMed]

194. Shimazaki, N.; Togashi, N.; Hanai, M.; Isoyama, T.; Wada, K.; Fujita, T.; Fujiwara, K.; Kurakata, S. Anti-tumour activity of cs-7017, a selective peroxisome proliferator-activated receptor gamma agonist of thiazolidinedione class, in human tumour xenografts and a syngeneic tumour implant model. Eur. J. Cancer 2008, 44, 1734-1743. [CrossRef] [PubMed]

195. Budman, D.R.; Calabro, A. Studies of synergistic and antagonistic combinations of conventional cytotoxic agents with the multiple eicosanoid pathway modulator ly 293111. Anti-Cancer Drugs 2004, 15, 877-881. [CrossRef] [PubMed] 
196. Schwartz, G.K.; Weitzman, A.; O’Reilly, E.; Brail, L.; de Alwis, D.P.; Cleverly, A.; Barile-Thiem, B.; Vinciguerra, V.; Budman, D.R. Phase i and pharmacokinetic study of ly293111, an orally bioavailable ltb4 receptor antagonist, in patients with advanced solid tumors. J. Clin. Oncol. 2005, 23, 5365-5373. [CrossRef] [PubMed]

197. Tong, W.G.; Ding, X.Z.; Talamonti, M.S.; Bell, R.H.; Adrian, T.E. Leukotriene b4 receptor antagonist ly293111 induces s-phase cell cycle arrest and apoptosis in human pancreatic cancer cells. Anti-Cancer Drugs 2007, 18, 535-541. [CrossRef] [PubMed]

198. Cleynen, I.; Boucher, G.; Jostins, L.; Schumm, L.P.; Zeissig, S.; Ahmad, T.; Andersen, V.; Andrews, J.M.; Annese, V.; Brand, S.; et al. Inherited determinants of crohn's disease and ulcerative colitis phenotypes: A genetic association study. Lancet 2016, 387, 156-167. [CrossRef]

199. Ricote, M.; Huang, J.; Fajas, L.; Li, A.; Welch, J.; Najib, J.; Witztum, J.L.; Auwerx, J.; Palinski, W.; Glass, C.K. Expression of the peroxisome proliferator-activated receptor gamma (PPARgamma) in human atherosclerosis and regulation in macrophages by colony stimulating factors and oxidized low density lipoprotein. Proc. Natl. Acad. Sci. USA 1998, 95, 7614-7619. [CrossRef] [PubMed]

200. Gosset, P.; Charbonnier, A.S.; Delerive, P.; Fontaine, J.; Staels, B.; Pestel, J.; Tonnel, A.B.; Trottein, F. Peroxisome proliferator-activated receptor gamma activators affect the maturation of human monocyte-derived dendritic cells. Eur. J. Immunol. 2001, 31, 2857-2865. [CrossRef]

201. Lewis, J.D.; Lichtenstein, G.R.; Deren, J.J.; Sands, B.E.; Hanauer, S.B.; Katz, J.A.; Lashner, B.; Present, D.H.; Chuai, S.; Ellenberg, J.H.; et al. Rosiglitazone for active ulcerative colitis: A randomized placebo-controlled trial. Gastroenterology 2008, 134, 688-695. [CrossRef] [PubMed]

202. Bertin, B.; Dubuquoy, L.; Colombel, J.F.; Desreumaux, P. PPAR-gamma in ulcerative colitis: A novel target for intervention. Cur. Drug Targets 2013, 14, 1501-1507. [CrossRef]

203. Pirat, C.; Farce, A.; Lebegue, N.; Renault, N.; Furman, C.; Millet, R.; Yous, S.; Speca, S.; Berthelot, P.; Desreumaux, P.; et al. Targeting peroxisome proliferator-activated receptors (PPARs): Development of modulators. J. Med. Chem. 2012, 55, 4027-4061. [CrossRef] [PubMed]

204. Avouac, J.; Konstantinova, I.; Guignabert, C.; Pezet, S.; Sadoine, J.; Guilbert, T.; Cauvet, A.; Tu, L.; Luccarini, J.M.; Junien, J.L.; et al. Pan-PPAR agonist iva337 is effective in experimental lung fibrosis and pulmonary hypertension. Ann. Rheum. Dis. 2017, 76, 1931-1940. [CrossRef] [PubMed]

205. Xu, P.; Hong, F.; Wang, J.; Wang, J.; Zhao, X.; Wang, S.; Xue, T.; Xu, J.; Zheng, X.; Zhai, Y. DBZ is a putative PPARgamma agonist that prevents high fat diet-induced obesity, insulin resistance and gut dysbiosis. Biochim. Biophys. Acta 2017, 1861, 2690-2701. [CrossRef] [PubMed]

206. Wang, J.; Xu, P.; Xie, X.; Li, J.; Zhang, J.; Wang, J.; Hong, F.; Li, J.; Zhang, Y.; Song, Y.; et al. DBZ (danshensu bingpian zhi), a novel natural compound derivative, attenuates atherosclerosis in apolipoprotein e-deficient mice. J. Am. Heart Assoc. 2017, 6, pii:e006297. [CrossRef] [PubMed]

207. Taniguchi, A.; Fukushima, M.; Sakai, M.; Tokuyama, K.; Nagata, I.; Fukunaga, A.; Kishimoto, H.; Doi, K.; Yamashita, Y.; Matsuura, T.; et al. Effects of bezafibrate on insulin sensitivity and insulin secretion in non-obese japanese type 2 diabetic patients. Metabolism 2001, 50, 477-480. [CrossRef] [PubMed]

208. Balakumar, P.; Rose, M.; Ganti, S.S.; Krishan, P.; Singh, M. PPAR dual agonists: Are they opening pandora's box? Pharmacol. Res. 2007, 56, 91-98. [CrossRef] [PubMed]

209. Pollock, C.B.; Rodriguez, O.; Martin, P.L.; Albanese, C.; Li, X.; Kopelovich, L.; Glazer, R.I. Induction of metastatic gastric cancer by peroxisome proliferator-activated receptordelta activation. PPAR Res. 2010, 2010, 571783. [CrossRef] [PubMed]

210. Fievet, C.; Fruchart, J.C.; Staels, B. PPARalpha and PPARgamma dual agonists for the treatment of type 2 diabetes and the metabolic syndrome. Curr. Opin. Pharmacol. 2006, 6, 606-614. [CrossRef] [PubMed]

(C) 2018 by the authors. Licensee MDPI, Basel, Switzerland. This article is an open access article distributed under the terms and conditions of the Creative Commons Attribution (CC BY) license (http:/ / creativecommons.org/licenses/by/4.0/). 